NBER WORKING PAPER SERIES

\title{
EXPLORING GENDER DIFFERENCES IN EMPLOYMENT AND WAGE TRENDS AMONG LESS-SKILLED WORKERS
}

\author{
Rebecca M. Blank \\ Heidi Shierholz \\ Working Paper 12494 \\ http://www.nber.org/papers/w12494
NATIONAL BUREAU OF ECONOMIC RESEARCH 1050 Massachusetts Avenue
Cambridge, MA 02138
August 2006

This paper was written for the conference sponsored by the National Poverty Center at the Gerald R. Ford School of Public Policy, University of Michigan, entitled Working and Poor: How Economic and Policy Changes are Affecting Low-Wage Workers, and held in Washington, D.C. on June 9-10, 2005. It will be appearing in a volume of the same title, published by the Russell Sage Foundation. Funding was provided by both the C.S. Mott Foundation and the Office of the Assistant Secretary for Planning and Evaluation, Department of Health and Human Services. Thanks are due to Ari Kushner and Emily Beam for excellent research assistance and to James Sallee for his help with construction of the data. The views expressed herein are those of the author(s) and do not necessarily reflect the views of the National Bureau of Economic Research.

(C2006 by Rebecca M. Blank and Heidi Shierholz. All rights reserved. Short sections of text, not to exceed two paragraphs, may be quoted without explicit permission provided that full credit, including @ notice, is given to the source. 
Exploring Gender Differences in Employment and Wage Trends Among Less-Skilled Workers

Rebecca M. Blank and Heidi Shierholz

NBER Working Paper No. 12494

August 2006

JEL No. J16, J31

\begin{abstract}
In contrast to less-skilled men, less-skilled women have experienced growing labor force involvement and moderate wage increases. Compared to more-skilled women, less-skilled women have fallen behind. We investigated the reasons behind these trends in labor force participation and wages for male and female workers of different skill levels over the past 25 years, from 1979-2004. We find that less-skilled women have found themselves in an 'intermediate' place in the labor market. Like less-skilled men, they experienced deteriorating returns to education but, unlike the men, they benefited from a growing positive impact of accumulated experience on labor market outcomes. More-skilled women experienced both growing returns to education and greater accumulation of experience, leading to faster wage growth. In addition, at the same time that experience levels have grown, the returns to experience on wages and labor force participation have also risen among less-skilled women, while the returns to experience have declined among less-skilled men. The negative effect of children and marital status on wages and labor force participation has also declined markedly among women of all skill levels.
\end{abstract}

Rebecca M. Blank

Gerald R. Ford School of Public Policy

735 S. State Street, Room 4300

University of Michigan

Ann Arbor, MI 48109-3091

and NBER

blank@umich.edu

Heidi Shierholz

Department of Economics

150 St. George Street

University of Toronto

Toronto, Ontario M5S 3G7

CANADA

heidi.shierholz@utoronto.ca 
As many of the papers in this volume emphasize, labor force participation and real wage rates among less-skilled men have fallen since the late 1970s. A substantial literature has investigated the declining returns to less-skilled jobs and the growing wage inequality between more and less-skilled workers in the U.S. labor market (Autor and Katz 1999; Autor, Katz, and Kearney 2005). Most of this literature has focused on men, however. While research on the effects of welfare reform has recognized growing labor force participation among less-skilled women, rarely have the very different trends among less-skilled men and women been directly compared. In contrast to their male colleagues, real wages among less-skilled women have not fallen and their labor force participation has in fact risen. This paper investigates trends in labor market outcomes for both male and female workers of different skill levels over the past 25 years. We look at gender differences by skill level in labor force participation and wages, exploring why less-skilled women have done better than less-skilled men in recent decades, even while losing ground relative to more-skilled women. This paper also provides background information for this volume, showing the comparative trends among more and less-skilled workers, by gender, since the late 1970 s.

The differential trends in labor market outcomes by skill and gender raise a number of questions. To what extent do these trends reflect differences in the human capital characteristics that men and women bring into the labor market? For instance, as we shall see, full-time work experience has risen among women and fallen among men; education levels have risen faster among women than among men. Alternatively, these trends may reflect differences in the jobs held by men and women and/or changes in the ways in which men and women's skills are valued. For instance, if discrimination against women has fallen in the past three decades, women may gain ground in the labor market relative to men. 
There is a large literature on trends in male/female wage differences among all workers (Altonji and Blank 1999; Bayard, et. al. 2003; Blau and Kahn forthcoming), but this literature gives little attention to gender differences by skill level (Blau and Kahn, 1997, or Blau, 1998, are exceptions). Furthermore, there is very little literature on differential trends in labor force participation between women and men. Two recent papers address this topic (Mulligan and Rubinstein 2005; Blau and Kahn 2005), but again, these papers do not look at differences across skill groups. This paper explores these gender/skill trends in a relatively simple way, identifying areas where more statistically and theoretically complex analyses might add to our ability to better understand these changes.

\section{Trends in Labor Market Outcomes by Skill Level and Gender}

In this section we examine long-term trends in four key labor market outcomes: trends in labor force participation rates, unemployment rates, wage rates, and the overall responsiveness of labor market outcomes to economic cycles. ${ }^{1}$ In each case, we present these trends over the past 25 years by gender and skill level. Throughout this paper we focus on men and women between the ages of 18 and 54. We define "less-skilled" as those whose highest educational credential is a high school degree or less and compare them to the "more-skilled," defined as those who have post-high school training. When discussing the less-skilled, we frequently distinguish between those with exactly a high school degree and high school dropouts. We analyze data from 1979 through 2004. The data in this section are based on tabulations from the Current Population Survey's Outgoing Rotation Groups (ORG) data; these data provide large annual samples. ${ }^{2}$

\footnotetext{
${ }^{1}$ We focus on labor force participation (working or actively looking for work) as opposed to employment because we think it is a better measure of labor force involvement. In Table 1, when we analyze cyclical patterns, we switch to employment (fraction of weeks worked) because that variable is more commonly used to measure cyclicality.

${ }^{2}$ The number of observations in a year ranges from 189,066 to 259,279 .
} 
Labor force participation. Figure 1 plots labor force participation rates, the share of all adults who are either at work or looking for work, for men (black lines) and women (gray lines) by skill level. Labor force participation among those with less than a high school degree is shown by the solid lines; among those with exactly a high school degree by the long dashed lines; and among those with more than a high school degree by the short dashed lines.

The most visible feature of Figure 1 is the narrowing over time of the male and female labor force participation gap. This trend is strongest among more-skilled men and women (the lines with short dashes), where the gender difference in labor market participation narrows from 21 percentage points in 1979 (91 percent for men and 70 percent for women) to 11 points in 2004 (90 percent for men and 79 percent for women). The declining gap is almost entirely due to substantial increases in labor market involvement among more-skilled women. Among lessskilled groups, the gender gap is larger and narrows at a somewhat slower rate. The gap fell from 37 points in 1979 to 24 points in 2004 among high school dropouts. This occurs because male labor force involvement falls and because female labor force involvement rises.

We do not show the results separately by race or ethnicity, but the equivalent graph using data only among Hispanics shows very similar trends. Among African Americans, labor force participation has converged more within each skill group than among whites. Among those with less than a high school degree, the decline in black male labor force participation is especially dramatic, so that there is only a 5-point gap between black men and women who are high school dropouts in 2004.

Unemployment rates. The unemployment rate shows the share of all labor market participants who are seeking jobs but have not found one. Figure 2 plots comparisons in 
unemployment rates between men and women by skill level. Equivalent graphs that look only at blacks or Hispanics show very similar results.

Among the more-skilled (short dashed lines), women's unemployment rates have converged with men's. In 1979 these rates were 5.0 percent and 3.2 percent for women and men, respectively; by 2004, they were 3.8 percent and 3.9 percent. Among those with exactly a high school degree (long dashed lines), women have been below or at the male unemployment rate throughout the period. Among high-school dropouts (solid lines), women's unemployment rates are consistently higher than men's and they are somewhat less cyclical. There is a slight widening in the gender unemployment gap among this least-skilled group during the 1990s. We suspect that this reflects the increased labor force participation among less-skilled women in the mid 1990s; with welfare reform, many low-skilled women with limited experience began to search for work.

Hourly wages. Figure 3 plots median real hourly wages over time within each gender and skill group. ${ }^{3}$ In 1979 , hourly wages among all female skill groups were lower than hourly wages among all male skill groups, so that women with more than a high school education earned less than male high school dropouts (\$10.62 versus \$10.94). More-skilled men and women both show substantial increases in earnings between 1979 and 2004, with slight convergence over time. Male earnings among the more-skilled increased by 12 percent, from $\$ 15.94$ to $\$ 17.83$, while equivalent women's earnings increased by 31 percent, from $\$ 10.62$ to $\$ 13.91$. The increase in wages among these more highly skilled workers is particularly dramatic since this group is a rapidly growing share of the population over time. ${ }^{4}$

\footnotetext{
${ }^{3}$ Adjusted to 2000 dollars with the GDP Personal Consumption Expenditures deflator.

${ }^{4}$ The most dramatic growth in wages occurs among the college-educated over this time period. There is more rapid convergence in male-female wages among this group as well.
} 
Less-skilled men - both high school graduates and high school dropouts - show real wage declines from 1979 through the mid-1990s. Their wages rise after 1995 but remain below where they were at the start of the period. In 2004, male high school dropouts earned $\$ 9.27$ per week, 15 percent below the 1979 level; high school graduates earned $\$ 12.80,6$ percent less than in 1979. In comparison, less-skilled women show rising wages over this period (high school dropouts earned \$7.08 in 1979 and \$7.42 in 2004; high school graduates earned \$8.50 in 1979 and $\$ 9.95$ in 2004.) The combination of declines in male wages and increases in female wages leads to a narrowing of gender wage differences among the less-skilled. The female/male ratio in 2004 is 0.80 for high school dropouts, 0.78 for high school graduates, and 0.78 for those with more education.

Equivalent graphs of hourly wages among only black or Hispanic workers show remarkably similar trends for less-skilled workers. Among the more-skilled, the black and Hispanic male/female gender wage gap has narrowed much more than among whites. This is largely because more-skilled men's wages in these groups have not risen as consistently as among more-skilled white males, so that rising wages among more-skilled black and Hispanic women have helped them catch up faster.

Changing relative wages between men and women have been linked with the trends toward rising inequality across skill groups. Blau and Kahn (1997) argue that widening wage inequality pulled less-skilled women's wages down in the 1980s, but that this was more than offset by improvements in women's experience and in their occupational placement. Welch (2000) suggests that men's widening wage inequality is causally linked with the declining gender gap in wages, as the technological shifts that caused losses to less-skilled men also brought 
relative gains to women. Fortin and Lemieux (2000) also present evidence consistent with this story.

Cyclicality. Finally, we look at the effect of cyclicality on male and female workers by skill level. Previous work suggests that men and women's labor market responsiveness to unemployment is generally similar, although less-skilled workers experience greater cyclicality than more-skilled workers (Hoynes 2000).

Table 1 shows the effect of changes in unemployment rates on men and women's labor market outcomes using pooled data from 1979 to 2003. The three dependent variables used in the analysis are the fraction of weeks worked in a year, log hourly wages, and log annual earnings. Within each gender and skill group, the table reports the coefficient on state unemployment rates in a regression that also includes state and year fixed effects, as well other variables identified at the bottom of the table.

The first two columns in Table 1 show the effect of a one percentage point increase in the state unemployment rate on the fraction of weeks worked in a year. In general, the fraction of weeks women work is only slightly less responsive to the economic cycle than the fraction men work. For instance, among all adults, a 1-point rise in unemployment leads to a 0.9-point drop in the fraction of weeks worked among men and a 0.8-point drop among women. For both men and women, the fraction of weeks worked is most cyclical among those with only a high school degree; a 1-point rise in unemployment leads to a 1.2 point drop in the fraction of weeks worked among men and a 0.9 point drop among women.

Not surprisingly, hourly wages display much less cyclicality (middle two columns of Table 1.) Women show no evidence of significant wage changes over the cycle. Among men, wages are somewhat cyclical - a one percentage point increase in the state unemployment rate 
reduces male hourly wages by 0.2 percent. Annual earnings, on the other hand, display considerable cyclicality (last two columns of Table 1.) The cyclicality in annual earnings is more pronounced for the less-skilled than for the more-skilled and more pronounced for men than for women. For men with less than a high school education, a one percentage point increase in the state unemployment rate reduces male annual earnings by 2.6 percent, whereas the reduction is 1.9 percent for equivalent women. Our analysis implies that the increase in unemployment during the recession of the early 2000s (from 4.0 in 2000 to 6.0 in 2003) should have caused a 3.8 percent decline in real annual earnings for low-skilled women and a 5.2 percent decline in real annual earnings for low-skilled men.

Although not shown in the table, for both men and women, cyclicality is much more pronounced for blacks and Hispanics than for whites. For example, while a 1-percent increase in the state unemployment rate reduces the real annual earnings of white females by 1.1 percent, it reduces the annual earnings of Hispanic females by 1.7 percent and of black females by 2.0 percent. (For men those numbers are 1.7 percent, 2.9 percent, and 3.7 percent, respectively.) The bottom line of this review of labor market trends is that less-skilled women have fared better than have less-skilled men. Their labor force participation has risen while it has fallen among equivalent men. Relative male/female unemployment rates have not changed much. Less-skilled women's wages have risen relative to their male peers, so that the female/male wage gap is about 50 percent lower than it was a quarter century earlier. Lessskilled women are also less disadvantaged by economic cycles than are less-skilled men. While more-skilled women have done even better, with greater gains in labor force participation and wages, so have more-skilled men, and these gains may reflect the overall growth in the labor 
market returns to skill. The remainder of this paper investigates why less-skilled women did better than their male counterparts.

\section{Exploring the Factors that Might Explain Changing Gender Differentials}

While there are many possible reasons for the substantial narrowing in gender differences in labor market outcomes, in this section we focus particularly on changes in experience and education. These are the two most-discussed human capital attributes among labor economists who study wage determination, and we describe the significant relative shifts over time in education and experience between men and women. At the end of this section, we briefly mention a variety of other factors that could also be accounting for gender shifts in the labor market. The discussion in this section provides background for the regressions in the following section.

Changes in experience. Past labor market experience is a key determinant of current labor market outcomes. During the prime working years, persons with more experience tend to earn more and are more likely to be in the labor market than those with less experience.

Historically, women's worse labor market outcomes have been partly ascribable to their lower levels of labor market experience, due to greater time spent in home production rather than market production, especially when they have small children. Over the last quarter century, however, increases in women's labor force involvement have led to greater accumulated labor market experience. Blau and Kahn (1997) suggest that a major reason why women did better than men in the 1980s is that their growing labor market experience offset some of the changes in the wage structure that worked increasingly against low-wage workers. 
To investigate changes in experience, we turn to the Panel Study of Income Dynamics (PSID), which contains longitudinal data on a national sample of the population over the past three decades. The PSID data, unlike the CPS data, provide information on actual accumulated labor market experience. ${ }^{5}$ Figure 4 shows the age-experience profile for less-skilled workers, plotting the relationship between age and accumulated full-time labor market experience separately for men and women in both 1979 and 2000.

In 1979, less-skilled women's full-time work experience increased about four months with each year of age between ages 18 and 54, whereas in 2000, full-time experience increased by about six months with each year of age. For less-skilled men, the story is reversed. In 1979 their full-time experience increased by 11 months with each year of age, whereas in 2000 it increased by only nine months. Thus, as Figure 4 demonstrates, between 1979 and 2000 there was a substantial narrowing of the gender gap in full-time experience among the less-skilled. There is a similar pattern of narrowing experience differentials among the more-skilled as well over this time period.

In addition to considerable changes in experience levels, the relationship between experience and labor market outcomes might have also changed. Historically, even at equivalent levels of labor market experience, women were less likely to work and earned less than men. These lower returns to experience may reflect different preferences that led women to select jobs where the returns were lower (but that may have had other benefits, such as flexible scheduling), or it may be due to discrimination against women that devalued their experience.

\footnotetext{
${ }^{5}$ PSID data from survey years 1980 and 2001 were used for this analysis. The sample was restricted to "heads" and "wives" aged 18-54 and was weighted using individual weights. Actual experience was obtained primarily from retrospective variables in which respondents were asked the number of years they had worked full time since they were 18. Missing data were filled in by calculating years of work based on annual surveys.
} 
Figure 5 investigates the relationship between accumulated experience and labor market participation among less-skilled women and men in 1979 and 2000, providing an “experience/participation” curve. At every level of experience in 1979, less-skilled women worked at significantly lower rates than men, but less-skilled women's propensity to work rose at every level of experience between 1979 and 2000. In contrast, men's propensity to work fell at every level of experience between 1979 and 2000.

By 2000, women with low levels of accumulated experience still tended to work less than men with low levels of accumulated experience. For example, among women with 4 to 5 years of experience the participation rate was 58 percent; for men with 4 to 5 years, it was 79 percent. However, labor market participation among women who were more attached to the labor market (those with 15 years of experience or more) was identical to their male counterparts by 2000 . The labor force participation rate among women with 16 to 25 years of experience was 87 percent; for equivalent men, it was 88 percent. Figure 4 suggests that women's labor force participation may have risen because their accumulated experience levels grew over the past several decades; figure 5 suggests that women's labor force participation also rose because their likelihood of working in 2000 was higher at every level of experience than it was in 1979.

Figure 6 shows the "experience/wage curve," plotting accumulated experience against current wages for less-skilled workers. Women's wage/experience profile is similar in 2000 and 1979 for women with 10 years of experience or less, but wages are higher among women with greater accumulated experience in 2000. In 2000, a less-skilled woman with 16 to 25 years of experience earned a median wage of $\$ 13.07$ dollars; in 1979 , she earned only $\$ 9.99$. Among less-skilled men, wages were lower at every experience level in 2000 compared to 1979, although their experience/wage curve remains above women's. Figure 6 suggests that women's 
relative wages may have risen not only because of greater accumulated experience but also because the relative returns to experience rose among women with high levels of work experience.

Changes in education. There have been substantial increases in educational attainment over the last quarter century, suggesting that less-skilled workers have become more negatively selected within the ability distribution in the population. If women's educational levels have changed at a different rate than men's, this could lead to differential labor market outcomes.

Figure 7 plots educational attainment levels for men and women. The lower (solid) lines show the share of high school dropouts in the total population by gender. These two lines lie almost on top of each other, suggesting that this group has shrunk as rapidly among men as women over time. By 2004, only 12 percent of women and 15 percent of men between the ages of 18 and 54 were high school dropouts. The top (dashed) lines show the share of the total population that is less-skilled - those with no more than a high school degree - by gender. Women were more likely to be less-skilled than men in 1979 (63 percent versus 56 percent) but they increased their education levels at a somewhat higher rate so that they are somewhat less likely to be in this category by 2004 (42 percent versus 47 percent). Figure 7 suggests that there have been substantial changes in the selectivity of both men and women into the more and lessskilled categories in our data. The more rapid decline in the share of less-skilled women suggests their (negative) selectivity should have been greater, however, which would drive women's wages down at a faster rate, all else equal. Selectivity cannot explain less-skilled women's improving labor market outcomes relative to men.

Historically, men and women with equivalent levels of education have worked different amounts over their lifetimes. This gendered relationship between education and labor market 
involvement might be shifting for reasons such as changes in expectations about market work careers among women, changes in the returns to work, or declining employer discrimination. As we will see below, there are substantial gender and skill differences in the wage returns to education. Declining gender discrimination might lead to relative female wage gains even when wages among the less-skilled are falling. Blau and Kahn (1997) provide evidence consistent with this over the 1980s.

We plot the relationship between education levels and labor force participation rates in 1979 and 2000 in Figure 8. ${ }^{6}$ Figure 8 shows labor force participation rising with years of education among both men and women. For example, in 2000 the rate for women with 10 years of education was 57 percent, whereas it was 83 percent for women with 16 years or more. In 2000, women at all education levels worked more than in 1979, while less-skilled men worked less, narrowing the gender gap. Figure 8 implies that increases in education might increase women's labor force participation both because more education leads to higher levels of market work and because work at every level of education has risen.

Figure 9 shows the relationship between education levels and median hourly wages. For both men and women, wages rise little at low levels of education, but faster as education increases. As expected, women with equivalent levels of education have lower wages. Among female workers who are high school dropouts, the education/wage relationship changed little over this period, but wages have risen among women with high school degrees or more. In short, we find the same pattern in Figure 9 as elsewhere: Rising education leads to rising wages, but even if education had not risen, women are earning more at most levels of education.

\footnotetext{
${ }^{6}$ Figures 8 and 9 are based on data from the Current Population Survey's Outgoing Rotation Groups, which provide large samples. We utilize 2000 as the end comparison date to make these figures comparable with the PSID data utilized in Figures 5 and 6 . Using 2004 data for Figures 8 and 9 would not effect on the results.
} 
Changes in the industrial distribution of jobs. Men and women have always worked in very different industries and occupations, and these differences are greater among less-skilled workers. Figure 10 demonstrates the differences in the distribution of jobs by industry among less-skilled men and women in 2002. Men are far more likely than women to be in agriculture, fisheries, mining, or construction (54 percent versus 7 percent) or manufacturing industries (39 percent versus 27 percent), while women are more likely to be in personal services (17 percent versus 4 percent) or professional service industries (48 percent versus 9 percent). A long literature has investigated the effects of differences in both industry and occupation on wages. For example, Bayard, et. al. (2003) find that occupational and industrial placement in the labor market explains about half of the gender wage gap.

Gender differences across the distribution of industries have changed little over the past 25 years. A standard index of industry segregation among less-skilled men and women was at 0.365 in 1983 and 0.390 in $2002 .^{7}$ This index also shows little change among more-skilled workers. Similarly, an occupation segregation index for less-skilled men and women was 0.482 in 1983 and 0.486 in 2002. This index falls significantly among more-educated workers, however.

Thus, gender segregation by occupation and industry has been largely invariant among less-skilled workers and can do little to explain differential gender trends in outcomes. It is worth noting that industry location does have real effects on cyclical trends in the labor market. Between 1999 (a business cycle peak) and 2002 (a year of sluggish economic growth), lessskilled men's unemployment rates rose from 4.9 percent to 7.4 percent, while less-skilled

\footnotetext{
${ }^{7}$ This index indicates the share of women (or men) that would have to change industry in order for men and women to have equal industry distributions. Industry and occupational coding change every 10 years, and it is difficult to recode across these breakpoints. We have translated the industry coding used from 1983-92 to the coding used from 1993-02, using crosswalk information provided by the U.S. Census Bureau.
} 
women's rates rose less, from 5.5 percent to 7.3 percent. All else equal, had women worked in the same industries as men, women's unemployment would have been higher in 1999, at 6.0 percent, and risen to 8.8 percent. $^{8}$

Fertility/marriage changes. Because women on average put much more time into child care and child rearing than men, changes in household composition and fertility are more likely to influence women's labor market involvement than men's. Even among men, however, research indicates that marriage influences labor market outcomes (Hellerstein and Neumark forthcoming). Over the past 25 years, there has been only a small increase in less-skilled women's propensity to stay single and childless, but their likelihood of being an unmarried mother has increased by 10 percentage points, from 12 to 22 percent. Their likelihood of being married has declined by 13 percentage points, from 68 to 55 percent, and the number of children in families has decreased.

The expected impact of changes in childbearing and marriage on women's labor market choices is unclear. On the one hand, women tend to work less when they have greater child-care responsibilities and substitute home production for market production. On the other hand, women's income needs rise with children, particularly if there are no earnings from a spouse or partner. As noted above, labor market outcomes and household composition are linked for women, so these household changes (especially declines in family size) may lead to wage changes. It is also worth noting that child-bearing and marriage may both be endogenous to labor market outcomes.

Other possible causes. Other less-easily measured factors can also influence differential gender trends in wages and labor force participation. First, changes in the legal landscape and in

\footnotetext{
${ }^{8}$ This simulation assigns women's actual unemployment rate within an industry, but weights women's employment across industries using men's industry share.
} 
public awareness of gender-based discrimination are likely to have made employers more open to hiring women, although this may have affected more-skilled women more than less-skilled if a main effect of discrimination had been to close off high-wage, high-status jobs to women (Blau and Kahn forthcoming). Changes in social norms and expectations about work among women with children have also changed over this time.

Second, changes in male incarceration rates may have influenced observed labor market outcomes among men. Since the 1970s, Congress and state legislatures have passed a variety of tougher sentencing policies that led to an unprecedented rise in incarceration rates concentrated among younger men, particularly younger minority men. ${ }^{9}$ Between 1979 and 2003, the male incarceration rate rose from 254 males in prison per 100,000 males in the population to 846 per 100,000. Less-skilled men were disproportionately affected by these changes. Raphael (2005) indicates that that net effect of these changes is to reduce labor force participation among the non-incarcerated in the most affected groups.

Third, as the paper by George Borjas (this volume) indicates, growing immigrant shares can also influence male/female labor market outcomes. Between 1980 and 2003, the foreignborn population in the United States increased from 6.2 to 11.7 percent, reflecting high rates of immigration. Immigrants may have different labor force participation patterns by gender; most noticeably, immigrant families often have lower female labor force participation, both because these families tend to have more children to care for and because of differences in cultural norms about working wives.

Fourth, U.S. policy changes have influenced women's work choices. During the 1990s, the U.S. made major efforts to move welfare recipients (typically less-skilled single mothers)

\footnotetext{
${ }^{9}$ This includes mandatory minimum drug sentencing laws, "three strikes" or habitual offender laws, and truth-insentencing laws that restrict the possibility of early release.
} 
into work. Single mothers' labor force participation rates rose faster than those of less-skilled childless or married women between 1989 and 1999. A number of studies indicate that these labor force changes were at least partially due to welfare reforms (Blank 2002), which could lead to less-skilled women's labor market participation increasing faster than men's. If more women enter the labor market and displace men, this can depress male labor force participation. Blank and Gelbach (2006) find no evidence of any impact of the 1990s increases in female labor force participation and associated changes in welfare programs on work behavior among low-skilled men. $^{10}$

Other policies also increased work incentives among the less-skilled, most notably increases in the Earned Income Tax Credit, which provided growing incentives for labor market entry among non-working household heads with children (primarily single mothers). The evidence suggests that the positive labor supply effects of the EITC were greater for single mothers than for married men. On the other hand, the EITC appears to have discouraged work among married women, so the net effect on gender-specific labor market trends is unclear (Hoffman and Seidman 2003).

While we believe that these other causal factors may be important in explaining gender differences in labor market outcomes, we have limited data on them. Policy changes vary only at the state level or the national level. Lacking individual level data on incarceration or immigration (before the early 1990s) in the CPS data, we can only measure these variables at the state level. State-level variables are poorly identified in cross-sectional data and (for reasons described below) we focus on cross-sectional estimates from 1979 and 2004. Given this, we opt to include state fixed effects in our regressions, and allow these fixed effects to absorb the impact

\footnotetext{
${ }^{10}$ Juhn and Kim (1999) look at the broader question of whether rising female labor supply has depressed male wages and find little evidence for such an effect.
} 
of demographic and policy differences across states that are not explicitly measured in our regressions.

\section{Estimating Labor Force Participation and Wages}

Based on the discussion in the previous section about the factors that might be affecting labor market outcomes among men and women, this section presents multivariate estimates of the determinants of two key labor market variables, labor force participation and wage rates. While many others have estimated such regressions, this analysis compares changes in the determinants of labor supply and wages over a 25 -year period, updating estimates such as those by Blau and Kahn (forthcoming), which go only through the 1990s. It focuses on differences in the determinants of labor market outcomes among different skill groups, rather than looking at aggregate results for men and women. It directly compares the determinants of wages and labor force participation. While our estimation approach is quite simple, these results allow us to compare changes across both of these labor market outcomes over time and among groups.

We estimate the determinants of labor force participation separately by gender and skill level in both 1979 and 2003. The four groups we focus on in each year are less-skilled men (those with a high school education or less), more-skilled men (those with more than a high school education), less-skilled women, and more-skilled women. The data come from the Annual Demographic Supplement to the March CPS in 1980 and 2004, which provides information on work and earnings in the previous year. We include all persons between the ages of 18 and 54. Labor market participation is a binary variable, equal to 1 if an individual reports working 1000 hours or more in the previous year. Imposing the 1000 hour restriction primarily gets rid of occasional and non-attached workers. Of those omitted by this restriction, over 75 
percent identify their primary activity as school or as taking care of home/family (rather than work), are retired, or identify themselves as ill or disabled. This restriction also gets rid of most outliers in hourly wages, which we calculate by dividing annual earnings by total annual hours (weeks worked times usual hours per week worked).

We focus on cross-sectional regressions in these two years, rather than utilizing stacked CPS cross-sections from all the years. Stacked data would provide better identification of a variety of coefficients (such as policy effects that change over time). Unfortunately, there are two selectivity issues changing over time that we do not know how to deal with effectively using stacked cross-sections. On the one hand, we believe that selectivity into the labor force has changed over time (among both men and women). On the other hand, selectivity into our skill groups has changed over time as well (see Figure 7). Because we are unable to deal adequately with these selectivity issues, we elect to estimate reduced-form regressions from the beginning and ending years of the period. We note that solving this dual-selectivity problem and estimating changing labor market outcomes over time is an important topic for future research. Alternatively, we could utilize longitudinal data (such as the PSID). Unfortunately, this provides much smaller sample sizes, particularly given the separate skill and gender samples that we need. We use a linear probability model to estimate labor force participation in a specific year (1979 or 2003) as follows:

$$
\mathrm{LFP}_{\mathrm{i}}=\beta_{0}+\mathrm{X}_{\mathrm{i}} \beta_{1}+\mathrm{Y}_{\mathrm{i}} \beta_{2}+\mathrm{Z}_{\mathrm{s}} \beta_{3}+\mu_{\mathrm{i}}
$$

where $\mathrm{i}$ indexes individuals in a particular gender/skill/year sample. $\mathrm{X}$ is a vector of personspecific variables that affect both wages and labor force participation and $\beta_{1}$ is the associated vector of coefficients. $\mathrm{X}$ includes years of education, potential experience (defined as ageeducation-5), race and ethnicity. In the wage equation that follows, $X$ also includes a control for 
part-time work. To allow for nonlinearity in returns to education for low-skilled workers, we also include a dummy variable to indicate if the person holds a high school degree.

$\mathrm{Y}$ is a vector of family-specific variables, with associated coefficient vector $\beta_{2}$. While we believe that these variables should primarily affect labor force participation decisions, there is evidence that marital status and children can affect wage outcomes as well. Y includes marital status, number of children, number of children under age 6 , number of infants, and whether the person is a single mother (for women only). $\mathrm{Z}$ is a vector of location-specific variables, with associated coefficient vector $\beta_{3}$. Z includes a set of state dummy variables that control for state fixed effects. Because we are estimating equation (1) separately in each year, these fixed effects control for any differences in the state environment, including differences in unemployment rates, unionization, welfare benefit levels and other welfare policy differences, state incarceration rates and policies, and other variables. $\mathrm{Z}$ also contains a dummy variable indicating whether an individual lives within a Standard Metropolitan Statistical area, providing a control for urban location.

We also estimate a wage equation for each gender/skill/year group:

$$
\operatorname{Ln}(\text { wage })_{i}=\alpha_{0}+X_{i} \alpha_{1}+Y_{i} \alpha_{2}+Z_{s} \alpha_{3}+\varepsilon_{i}
$$

where the dependent variable is the natural logarithm of real hourly wages, and other variables are defined as before.

We do not do selectivity corrections on our wage estimates, that is, we do not take account of who is working or not working in estimating wages. Instead, our wage regressions can be viewed as reduced-form regressions. The coefficients show not only the effects of these variables on wage determination, but also reflect the impact of these variables on who chooses to work (and hence, who has reported wages.) We report the reduced form rather than the 
selectivity-corrected estimates for several reasons. First, because we are estimating these regressions separately by skill level, we suspect that the biggest selectivity effect over time is due to changes in who is in each skill grouping (see Figure 7). There is no obvious way to control separately for this type of selectivity and we suspect that skill selectivity is tangled with factors (such as family composition) that are typically used to identify selection into the labor force.

Second, we estimated a large number of standard selectivity-corrected wage regressions in preliminary work for this paper, and we found that the wage coefficients (particularly the education coefficients) were extremely sensitive to how we identified the selectivity effect. This reinforces our concern that selectivity into these skill groupings is influencing the results and that we cannot interpret the selectivity coefficient in the standard manner (that is, as representing selectivity into the labor force only). Given these concerns, we prefer to report the descriptive reduced form wage regressions in this paper. By controlling for family composition variables (the $\mathrm{Y}$ vector) in the wage regression, we hope that we have absorbed at least some of the labor force participation selectivity effects (as well as some of the skill group selectivity) with these variables, but we recognize that our coefficients on the $\mathrm{X}$ vector are likely to be affected as well. We emphasize that this means the coefficients on the wage regression cannot be interpreted as the direct effect of these variables on wage determination alone.

We do not include dummy variables for industry and occupation. We prefer to think of industry and occupation selection as a joint outcome with wages, rather than including them as controls in a wage regression. For instance, if labor market discrimination against women in manufacturing forces them into service occupations, then including these variables "overexplains" gender wage differentials by ascribing to occupational choice what should be ascribed 
to discrimination. As we note above, these variables change little over time and are not likely to explain a great deal of the change in male/female wages, which is the focus of our concern. ${ }^{11}$

Table 2 shows the results from eight regressions estimating the determinants of labor force participation for men and women by skill level in 1979 and 2003 . The coefficients in the first row show that each additional year of education has a positive and significant effect on labor force participation, as expected (except among less-skilled men in 2003 without high school degrees). This education effect is stronger among less-skilled women than less-skilled men, consistent with the data in Figure 8. Over time, the impact of a year of education on labor force participation declines among both male and female high school dropouts, but the returns to a high school degree rise. In 2003, a male (female) worker with a high school degree had a 12.4 (17.0) percent higher probability of being in the labor force than a high school dropout with 11 years of education.

Experience has a positive effect on labor force participation among all groups and this effect grows over time except among more-skilled men. In 2003, increasing potential experience from 5 to 10 years raises the likelihood of labor market involvement by 5 percent for a female high school graduate, and by 4 percent for an equivalent man.

The effect of race on labor market involvement is relatively constant over time, except among less-skilled black men who are far less likely to work in 2003 than in 1979. By 2003, a less-skilled black man was 10 percent less likely to work than an equivalent white man. All else equal, race and Hispanic ethnicity have no differential effect on labor force participation among less-skilled women. Hispanic ethnicity is associated with higher levels of work among all other groups in 2003 .

\footnotetext{
${ }^{11}$ We estimated equivalent wage regressions including controls for occupation and industry. The results are generally consistent with those in Table 3, but show smaller returns to education and smaller race and ethnicity effects.
} 
Not surprisingly, family characteristics have a different effect on less-skilled women's labor force participation than on men's. As others have noted, marriage has a positive effect on men's labor market involvement and a negative effect on women's, although our estimates indicate that this effect has virtually disappeared over time among women. In contrast, single parenting has a positive effect on labor supply among more-skilled women (true in both years). While less-skilled single mothers were no more likely to work than equivalent unmarried childless women (the omitted category) in 1979, by 2003 their labor force participation is higher. One might interpret this as the result of the policy efforts to increase labor supply among welfare recipients.

In general, we expect that having more children, especially more young children, will decrease the likelihood of labor force involvement among women. ${ }^{12}$ The number of preschoolers variable indicates whether there is any differential effect of preschoolers, after controlling for total number of children. The number of infants variable indicates whether there is a differential effect of infants, after controlling for number of preschoolers. By 2003, among less-skilled women, the number of children over the age of five was unrelated to labor force participation, while the negative effect of children under age five was somewhat larger than in 1979. Moreskilled women's labor market choices have become less affected by the number and ages of children over time.

Table 3 presents the coefficients on the wage equations by year and gender, using a specification similar to that in Table 2. Because the dependent variable is log wages, one can interpret the coefficients in Table 3 as the percentage effect on wages of a one-unit change in the independent variable. Higher education levels lead to higher wages, as expected. Among both

\footnotetext{
${ }^{12}$ Surprisingly, we know of almost no research that investigates the effects of family composition on male labor supply, although we find significant effects in Table 2. Angrist and Evans (1998) indicate that number of children has little effect on fathers' labor supply, within a very particular family composition experiment.
} 
men and women who are high school dropouts, the returns to each year of education have fallen slightly, from 3.6 percent to 2.6 percent per year of education for women and from 4.7 percent to 3.6 percent per year of education among men. The wage returns to a high school degree has increased. Among men, the additional gain in wages from a high school degree rises from 9.3 percent in 1979 to 16.1 percent in 2003. Among women, the gain from finishing high school goes from 10.5 percent to 18.0 percent in 2003 . The returns to additional years of education have risen among more-skilled men and women as well. This is consistent with other evidence on the changing returns to education across skill groups.

In contrast, the wage returns to experience have remained relatively constant over time for all groups shown in Table 3. The combined coefficients on potential experience and its square indicate that an increase in potential experience from 5 to 10 years increases wages by 11 percent among women and 12 percent among men in 2003. We worry that our coefficients on experience are hard to interpret since we can only measure potential experience in the CPS rather than actual years of work experience. To check this, we have estimated equivalent regressions using a measure of actual experience, with PSID data from 1980 and 2001. Somewhat surprisingly, the experience variables in the PSID estimates are quite close to those in the CPS estimates. For instance, in the 2001 PSID, the returns to experience for the less skilled are estimated at 5.8 percent for men and 3.4 percent for women. These compare to 2003 estimates in Table 3 of 3.2 percent and 2.9 percent. Among more-skilled workers, the returns to experience are 4.7 percent (CPS) versus 4.8 percent (PSID) among men and of 4.3 percent (CPS) and 4.6 percent (PSID) among women. These comparisons reassure us that our potential experience estimates from the CPS are not too unreliable. Because of the much larger CPS sample sizes, we prefer to utilize this data set. 
Workers who are black or of Hispanic origin earn lower wages than white workers, all else equal. For instance, in 2003, less-skilled black workers, both male and female, earn about 14 percent less than equivalent white workers. More-skilled black men earn 17 percent less and more-skilled black women earn 6 percent less than equivalent white workers. The negative impact of Hispanic ethnicity on wages is even greater in 2003, with less-skilled Hispanic men earning 30 percent less and less-skilled Hispanic women earning 21 percent less. Of course, this can reflect discrimination in the labor market against workers of color or it may reflect differential skill levels that are not well measured in the other variables. For instance, black or Hispanic workers may have attended worse schools, or Hispanic workers may have more limited English skills. As expected, part-time work also results in lower wages. For less-skilled male workers, the negative wage effects of part-time work appear to have grown over time.

Finally, at the bottom of Table 3 we show the effect of a variety of family and children variables on wages. As discussed above, because we believe that the coefficients on these variables reflect selectivity into work as well as any direct effect of the variables on wages, we do not want to interpret the coefficients too strongly. Some of these variables may have a direct effect on wages; for instance, the literature suggests that married workers have higher productivity (Hellerstein and Neumark forthcoming). Consistent with this literature, we find that marriage has a positive correlation with the wages of all groups in both years, although the effects are bigger among men.

Other variables (such as the children variables) may reflect the selection of who works. For instance, if women with more children generally prefer not to work, it may be only lowincome mothers with larger families who can't afford to stay home who remain in the work force. This would result in a negative coefficient on number of children. Alternatively, if infant 
and preschool care is expensive, only higher-wage women may be able to afford to pay child care and work. This would result in a positive coefficient on the preschooler and infant variables. As we expect, the presence of children in the household has bigger and more significant effects on women's wages than men's, almost surely reflecting both which women go to work as well as the types of jobs they take.

Two broad generalization from Tables 2 and 3 should be noted. First, the determinants of labor force participation and wages differ substantially by gender, and these differences have changed over time. Second, the determinants of labor force participation and wages differ substantially by skill group, and these differences have also changed over time. Because it is hard to interpret the overall effects of these changes by looking at the estimates in Tables 2 and 3 , we turn to a decomposition that summarizes these results in the next section.

\section{What Has Caused Changes in Relative Wages Among Less-skilled Women?}

In this final section, we use the estimates from Tables 2 and 3 to calculate how changing factors are influencing relative labor force and wage changes among less-skilled women. We utilize a simple decomposition that characterizes the change in wages (or labor force participation) between two periods as

$$
\Delta(\text { lnwage })=(\Delta X) \hat{a}_{1}+(\Delta \hat{\mathrm{a}}) \mathrm{X}_{2},
$$

where $\Delta$ indicates the change between period 1 (1979) and period 2 (2003) in the means of the indicated variable, $X_{t}$ is a vector of the means of all variables in the regression in period $t$, and $\hat{a}_{t}$ is the vector of estimated coefficients on each variable in period t. Comparing the results from this decomposition between less-skilled men and women and between less-skilled women and 
more-skilled women, gives us a sense of the different changes that are occurring in the labor market over time. $^{13}$

Table 4 shows the results from these decompositions for changes in labor force participation rates. The first two rows show the level values of labor force participation for each group in 2003 and 1979, and the third row shows the change over time. The next four rows decompose this total change into the change due to education variables, experience variables, family composition variables (including marital status and children), and all other variables (including the race, ethnicity, SMSA, and state fixed effects). By including the state fixed effects (the equivalent of 50 state constants) in the "other variables" category, we subsume into this category any unexplained effects that are part of the constant, including shifts in discrimination. Below this, we decompose these factors into the amount due to changes in the means of the explanatory variables and to changes in the coefficients over time. The first three columns compare less-skilled women and men; the last three columns compare less-skilled and more-skilled women.

Look first at labor force participation changes over time among less-skilled women, the first column on the left hand side of Table 4 . The 8.3 percentage point increase in labor force participation rates among less-skilled women is being driven by changes in the effects of experience and family composition. These factors driving up labor force participation are offset somewhat by changes in education and in other variables that would have reduced labor force participation. The next several rows indicate that almost none of the change in women's labor force participation is due to changes in the mean levels of the X's; virtually all of it is due to changes in the coefficients, where the declining effect of education on labor supply for lessskilled women is more than offset by the growing positive effect of experience and family

\footnotetext{
${ }^{13}$ Others (i.e., Blau and Kahn 1997 and 2004) have done more complex decompositions.
} 
composition (more accurately, the negative effects of family composition on women's labor force participation are becoming smaller over time.)

In contrast, the 6.5 point decline in labor force participation among low-skilled men (column 2) is dominated by substantial declines in the coefficients on education that are only somewhat offset by the growing positive effect of experience on labor force participation. The declining effect of education on less-skilled men's labor force participation - the 11.0 point change in the coefficient on education - is driving much of the decline in male labor force participation.

As column 3 indicates, the gap in male-female labor force participation falls by almost 15 percentage points, mostly due to shifts in the relative returns on education, experience, and family variables that favored low-skilled women. These positive factors for relative female labor supply were at least partially offset by a shift in the other variables that has favored low-skilled men over women.

The three columns on the right-hand side of Table 4 compare labor force participation changes among less-skilled women with more-skilled women. Labor force participation rates grow a little more slowly among the less-skilled (by 8.3 points versus 10.0 points among the more-skilled), widening the gap between these groups by 1.7 percentage points. The effect of education on labor supply has declined markedly among more-skilled women, because the coefficient on education has fallen sharply. Essentially, most of these women now work, so the slope of labor supply by years of education has become flatter. This effect is more than offset by increasing positive effects on labor supply from all other variables. Most notably, the changing effect of family composition drove up labor supply among both less and more-skilled women. The "other" variables (race/ethnicity effects, SMSA location, and unexplained state-specific 
constants) shifted in ways that enhanced the labor force participation of more-skilled women while reducing the labor force participation of less-skilled women.

It is striking that so little of the change in labor force participation is due to actual changes in education or experience, but rather these changes are largely driven by changing coefficients. (Of course, the use of potential experience rather than actual experience understates the actual gain in years of labor market experience among women.) This conclusion about the importance of the coefficients is stronger than in previous work by Blau and Kahn, who find that both changes in the X's and change in coefficients are affecting the male/female wage gap. In part, this reflects the fact that we separate our sample by skill level; each skill group has smaller average changes in education and experience than does the total sample across all skill groups.

The strong effects of changing coefficients can reflect changing demand for different types of work, as well as changes in labor market discrimination. Relative to less-skilled men, the returns to less-skilled women's characteristics improved more (experience and family composition) or deteriorated less (education). Relative to more-skilled women, the returns to some characteristics improved more (experience and family composition) or deteriorated less (education), while race/ethnicity and unexplained factors greatly advantaged more-skilled women's labor force participation.

Table 5 decomposes real wage changes in a similar way, and has a similar organization. One can read changes in log wages as (approximately) equal to percentage changes, so the left two columns suggest that less-skilled women's wages rose 13.4 percent while men's fell 6.5 percent between 1979 and 2003, leading to a 19.9 percent narrowing in the male/female wage gap for less-skilled workers. In contrast, more-skilled women's wages (column 5) rose 29.6 percent, so the more-skilled/less-skilled wage gap among women rose by 16.2 percent. 
As with labor force participation, almost all of the change in less-skilled women's wages was due to changes in the coefficients rather than changes in the means of the explanatory variables. Returns to education fell among less-skilled women (by 5.1 points), while their returns to experience rose (4.6 points). Less-skilled men show falling returns to both education and experience over this time period. Family composition changes enhanced women's wages while they reduced men's wages. Hence, the overall reduction of 19 percent in the wage gap between less-skilled men and women is largely explained by shifts in the impact of education, experience, and family composition on wages that favored less-skilled women over less-skilled men.

Comparing more and less-skilled women gives a very different story. Unlike the lessskilled, more-skilled women saw strong increases in the wage returns to education, so the overall effect of education on more-skilled women's wages is strongly positive, while it is negative for the less-skilled. ${ }^{14}$ Both more and less-skilled women experienced increases in returns to experience as well as positive shifts in the effect of family variables on wages. More-skilled women also had greater gains in potential experience levels than did less-skilled women. The gains from these changes were partially offset by changes in the other variables that reduced wages somewhat among more-skilled females.

The message from Tables 4 and 5 is that the characteristics of low-skilled women are not changing much relative to those of low-skilled men or more-skilled women (although the women are gaining experience and the men are not.) Instead, the primary factor driving differential wage and labor force participation changes among these groups are differential changes in the coefficients that link worker characteristics to labor market involvement and wages. The impact

\footnotetext{
${ }^{14}$ The mean education level among more-skilled women declines between 1979 and 2003. A growing group of women are moving into the more-skilled (i.e., more than a high school degree) group. Since most of this movement is occurring at the margin, it means that overall years of education among this group decrease slightly.
} 
of education on labor force participation and wages among less-skilled men and women has deteriorated, but it has deteriorated more for men. The returns to experience (as a driver for both wages and labor force participation) have grown for all women. The effect of family characteristics on labor market and wage behavior among less-skilled women has changed in ways that increase their work and their wages, an effect that is also evident among more-skilled women. These changing coefficients can be the result of changes in labor market demand and employer behavior as well as changes in women's behavior over the past 25 years. This paper cannot pinpoint the reasons behind these shifts, but it does indicate that it is the translation between personal characteristics and labor market outcomes that are shifting differentially across groups.

\section{Conclusions}

This paper has investigated why less-skilled women have done relatively better than their less-skilled male counterparts over the last several decades, even while they have lost ground relative to more-skilled women. While education levels have grown among less-skilled women over this period, they have grown almost as fast among less-skilled men. Accumulated labor market experience has grown among both more and less-skilled women, although it has grown faster among the more-skilled. In the end, however, changes in the levels of these characteristics are not the dominant force behind different labor market trends among these groups. Instead, there have been large changes in the relationship between worker characteristics and labor market outcomes. On the one hand, less-skilled women experienced declining returns to education while the wage returns to education grew among more-skilled women, consistent with widening wage inequality between skill groups. There has been a growing positive effect of 
experience on labor market participation and on wages among women at all skill levels, while the effect of experience on wages among less-skilled men has declined. Furthermore, shifts in the effect of family composition on less-skilled women's labor supply have increased women's relative labor force participation, and these effects were greater among the less-skilled than the more-skilled.

Less-skilled women have thus found themselves in an "intermediate" place in the labor market. They have experienced deteriorating returns to education, but they have benefited from a growing positive impact of accumulated experience on labor market outcomes, offsetting some of the declining educational effects. This has worked to close the gender gap in wages among less-skilled workers. In contrast, less-skilled women's labor market outcomes have improved at a much slower rate than those of more-skilled women, who benefited from improvements in the returns to both experience and education. While more-skilled women are doing well, they continue to lag behind more-skilled men whose wages rose equally fast.

It would be useful to understand the shifts discussed above more fully. Why are the labor market returns to women's accumulated experience rising? To what extent does the shifting relationship between children, marriage, and women's work reflect changes in institutional structure, such as growing availability of child care? Nailing down causal interpretations will require more careful empirical work that accounts for changing selectivity effects and that looks at changes between cohorts over time rather than pooling the entire adult age distribution.

While less-skilled women have done better than less-skilled men in the labor market in the recent past, it is not clear that this pattern will continue. As the determinants of women and men's labor market outcomes converge, this may be bad news for less-skilled women, who may find themselves more subject to the negative trends that have disadvantaged less-skilled men for 
the past 25 years. Policies that subsidize work among the less-skilled, such as the EITC, child care, or health-care subsidies, will be of ongoing importance to encourage labor market participation and reward work among low-wage and low-skilled workers. 


\section{References}

Altonji, Joseph G., and Rebecca M. Blank. 1999. "Race and Gender in the Labor Market." In Handbook of Labor Economics, Volume 3C, edited by Orley C. Ashenfelter and David Card. Amsterdam: Elsevier.

Angrist, Joshua D., and William N. Evans. 1998. "Children and Their Parents' Labor Supply: Evidence from Exogenous Variation in Family Size.” American Economic Review 88(3): 450-77.

Autor, David H., and Lawrence F. Katz. 1999. "Changes in the Wage Structure and Earnings Inequality." In Handbook of Labor Economics, Volume 3A, edited by Orley C. Ashenfelter and David Card. Amsterdam: Elsevier.

Autor, David H., Lawrence F. Katz, and Melissa S. Kearney. 2005. “Trends in U.S. Wage Inequality: Reassessing the Revisionists.” NBER Working Paper No. 11627. Cambridge, MA: National Bureau of Economic Research.

Bayard, Kimberly, Judith Hellerstein, David Neumark, and Kenneth Troske. 2003. "New Evidence on Sex Segregation and Sex Differences in Wages from Matched Employee-Employer Data." Journal of Labor Economics 21(4): 887-922.

Blank, Rebecca M. 2002. "Evaluating Welfare Reform in the U.S." Journal of Economic Literature 40(4): 451-68.

Blank, Rebecca M., and Jonah Gelbach. 2006. "Are Less-Educated Women Crowding LessEducated Men Out of the Labor Market? In Black Males Left Behind, edited by Ron Mincy. Washington, D.C.: Urban Institute Press.

Blau, Francine D. 1998. “Trends in the Well-Being of American Women, 1970-1995." Journal of Economic Literature 36(1): 112-165.

Blau, Francine D., and Lawrence M. Kahn. 1997. "Swimming Upstream: Trends in the Gender Wage Differential in the 1980s.” Journal of Labor Economics 15(1, pt1): 1-42.

—. Forthcoming. "The U.S. Gender Pay Gap in the 1990s: Slowing Convergence." Industrial and Labor Relations Review.

—. 2005. "Changes in the Labor Supply Behavior of Married Women: 1980-2000." NBER Working Paper No. 11230. Cambridge, MA: National Bureau of Economic Research.

Fortin, Nicole M., and Thomas Lemieux. 2000. “Are Women's Wage Gains Men's Losses? A Distributional Test." American Economic Review 90(2): 456-60.

Hellerstein, Judith K., and David Neumark. Forthcoming. "Production Function and Wage Equation Estimation with Heterogeneous Labor: Evidence from a New Matched EmployerEmployee Data Set." In Hard to Measure Goods and Services: Essays in Honor of Zvi 
Griliches, edited by Ernst R. Berndt and Charles M. Hulten. Chicago: University of Chicago Press.

Hoffman, Saul D., and Laurence S. Seidman. 2003. Helping Working Families: The Earned Income Tax Credit. Kalamazoo, MI: Upjohn Institute.

Hoynes, Hilary W. 2000. "The Employment, Earnings and Income of Less Skilled Workers Over the Business Cycle." In Finding Jobs: Work and Welfare Reform, edited by David Card and Rebecca M. Blank. New York: Russell Sage.

Juhn, Chinhui, and Dae Il Kim. 1999. "The Effects of Rising Female Labor Supply on Male Wages." Journal of Labor Economics 17(1): 23-48.

Mulligan, Casey B., and Yona Rubinstein. 2005. "Selection, Investment and Women's Relative Wages Since 1975." NBER Working Paper No. 11159. Cambridge, MA: National Bureau of Economic Research.

Raphael, Steven. 2005. “The Socioeconomic Status of Black Males: The Increasing Importance of Incarceration." In Poverty, the Distribution of Income, and Public Policy, edited by Alan Auerbach, David Card, and John Quigley. New York: Russell Sage.

Welch, Finis. 2000. "Growth in Women's Relative Wages and in Inequality Among Men: One Phenomenon or Two?" American Economic Review 90(2): 444-49. 


\section{Table 1}

\section{Responsiveness of Labor Market Outcomes to Unemployment Changes, by Gender and Skill Level}

\begin{tabular}{|c|c|c|c|c|c|c|}
\hline \multirow[b]{2}{*}{ Skill Level } & \multicolumn{2}{|c|}{$\begin{array}{c}\text { Fraction of Weeks } \\
\text { Worked }\end{array}$} & \multicolumn{2}{|c|}{$\begin{array}{c}\text { Real Log Hourly } \\
\text { Wages }\end{array}$} & \multicolumn{2}{|c|}{$\begin{array}{l}\text { Real Log Annual } \\
\text { Earnings }\end{array}$} \\
\hline & Men & Women & Men & Women & Men & Women \\
\hline Less than $\mathrm{HS}$ & $\begin{array}{l}-0.007^{*} \\
(0.001)\end{array}$ & $\begin{array}{l}-0.006^{*} \\
(0.001)\end{array}$ & $\begin{array}{l}-0.003 \\
(0.002)\end{array}$ & $\begin{array}{l}-0.004 \\
(0.003)\end{array}$ & $\begin{array}{l}-0.026^{\star} \\
(0.003)\end{array}$ & $\begin{array}{l}-0.019^{*} \\
(0.005)\end{array}$ \\
\hline Exactly HS & $\begin{array}{l}-0.012^{*} \\
(0.001)\end{array}$ & $\begin{array}{l}-0.009^{*} \\
(0.001)\end{array}$ & $\begin{array}{l}-0.005^{*} \\
(0.001)\end{array}$ & $\begin{array}{c}0.001 \\
(0.001)\end{array}$ & $\begin{array}{l}-0.027^{*} \\
(0.002)\end{array}$ & $\begin{array}{l}-0.014^{*} \\
(0.002)\end{array}$ \\
\hline More than HS & $\begin{array}{l}-0.006^{*} \\
(0.000)\end{array}$ & $\begin{array}{l}-0.005^{\star} \\
(0.001)\end{array}$ & $\begin{array}{l}-0.004^{*} \\
(0.001)\end{array}$ & $\begin{array}{c}0.000 \\
(0.001)\end{array}$ & $\begin{array}{l}-0.019^{*} \\
(0.002)\end{array}$ & $\begin{array}{l}-0.013^{*} \\
(0.002)\end{array}$ \\
\hline All & $\begin{array}{l}-0.009^{*} \\
(0.000)\end{array}$ & $\begin{array}{l}-0.008^{*} \\
(0.000)\end{array}$ & $\begin{array}{l}-0.002^{*} \\
(0.001)\end{array}$ & $\begin{array}{l}0.001 \\
(0.001)\end{array}$ & $\begin{array}{l}-0.021^{*} \\
(0.001)\end{array}$ & $\begin{array}{l}-0.014^{*} \\
(0.001)\end{array}$ \\
\hline
\end{tabular}

Each number shows the coefficient on the state unemployment rate from a regression based on pooled CPS samples for this group from 1979 through 2003. State and year fixed effects are included. Other variables included in the regression are years of education; potential experience and potential experience squared; dummy variables to indicate race, Hispanic ethnicity, and location in an SMSA; dummy variables to indicate whether an individual is married or a single mother (women only); number of children, number of preschoolers, and number of infants. The wage regressions also include a control for part-time work.

* Significant at $5 \%$ level or higher. 
Table 2

Determinants of Labor Force Participation, by Gender and Year

1979

\begin{tabular}{cccc}
\hline & Men & \multicolumn{2}{c}{ Women } \\
\cline { 2 - 4 } HS or & More & HS or & More \\
$\underline{\text { LesS }}$ & than $\underline{\mathrm{HS}}$ & $\underline{\text { Less }}$ & than $\underline{\mathrm{HS}}$ \\
$0.013^{* *}$ & $0.008^{* *}$ & $0.018^{* *}$ & $0.037^{* *}$ \\
$(0.002)$ & $(0.002)$ & $(0.002)$ & $(0.003)$
\end{tabular}

Years of

Education

HS Degree

(1=yes)

Potential

Experience

Potential Exp

Squared

Race

(1=Black)

Ethnicity

(1=Hispanic)

Marital Status

(1=married)

Hhold Status

(1=Single Mom)

Number of

Children

Number of

Preschoolers

Number of

Infants

Observation
$0.038^{* *}$

(0.010)

$0.008^{* *} \quad 0.034^{* *}$

(0.001) (0.002)

$0.107^{\text {** }}$

(0.010)

$0.009^{* *} \quad 0.023^{* *}$

(0.001)

(0.002)

$-0.021^{* *}-0.066^{\star *}$

(0.003)

(0.005)

$\begin{array}{ll}-0.023^{\star *} & -0.091 \\ (0.003) & (0.004)\end{array}$

$-0.026^{*} \quad 0.057^{\text {** }}$

(0.011)

(0.017)

(0.011)

(0.016)

(0.011)

(0.018)

$0.013 \quad 0.014$

(0.011)

(0.021)

$-0.148^{* *}-0.087^{* *}$

$0.151^{\text {** }}$

$0.141^{* *}$

(0.008) (0.010)

$(0.010) \quad(0.013)$

$-0.002$

$0.111^{\text {** }}$

(0.012)

(0.019)

$-0.015^{* *}-0.024^{* *}$

$(0.002) \quad(0.003)$

$(0.002) \quad(0.002)$

$-0.020^{* *}-0.051^{* *}$

$(0.005)$

(0.008)

$-0.034^{* *}$

0.005

(0.012)

$(0.007)$

$(0.007)$

$\begin{array}{llll}25047 & 17373 & 30660 & 15708\end{array}$
$0.043^{* *}-0.014$
2003

\begin{tabular}{cccc}
\multicolumn{2}{c}{ Men } & \multicolumn{2}{c}{ Women } \\
\cline { 3 - 4 } HS or & More & HS or & More \\
$\underline{\text { LesS }}$ & than $\underline{\mathrm{HS}}$ & $\underline{\text { LesS }}$ & than $\underline{\mathrm{HS}}$ \\
-0.002 & $0.019^{* *}$ & $0.012^{* *}$ & $0.027^{* *}$ \\
$(0.002)$ & $(0.002)$ & $(0.003)$ & $(0.002)$
\end{tabular}

$0.126^{* *}$

$0.158^{* *}$

(0.012)

(0.012)

$0.015^{* *} \quad 0.028^{* *}$

$0.014^{* *} \quad 0.018^{\text {** }}$

(0.001) (0.001)

(0.001)

(0.001)

$\begin{array}{llll}-0.041^{* *} & -0.074^{* *} & -0.026^{* *} & -0.040^{* *}\end{array}$

(0.003) (0.004)

$(0.004)$

(0.004)

$-0.097^{\star *} \quad-0.036^{\star *}$

$-0.0140 .043^{* *}$

$(0.012) \quad(0.011)$

$(0.012) \quad(0.010)$

$0.087^{\star *} \quad 0.033^{\star *}$

$0.000 \quad 0.026^{*}$

(0.010) (0.011)

$(0.011)$

$(0.011)$

$0.145^{* *} \quad 0.126^{* *}$

(0.008) (0.007)

$-0.023$

$-0.019$

$(0.012) \quad(0.010)$

$0.086^{* *} \quad 0.112^{* *}$

(0.013) (0.011)

$\begin{array}{lccc}0.008^{\star *} & 0.003 & 0.000 & -0.009^{\star *} \\ (0.002) & (0.002) & (0.003) & (0.002)\end{array}$

$0.000 \quad 0.001$

$-0.029^{* *}-0.038^{* *}$

(0.006) (0.004)

$(0.006)$

(0.005)

$0.008 \quad 0.013^{*}$

$-0.040^{*}$

0.005

$(0.009) \quad(0.007)$

$(0.009)$

(0.008)
$23188 \quad 28174$

Note: All regressions include controls for location (SMSA) and state fixed effects. Potential experience is defined as age-education-5; coefficient on potential experience squared is multiplied by 100 . Number of children is the total number of children in the family less than age 18; number of preschoolers is the total less than age 6; and number of infants is the total less than age 2.

* Significant at $5 \%$ level or higher. Standard errors in parentheses.

** Significant at $1 \%$ level or higher. 
Table 3

Determinants of Log Wages, by Gender and Year

\begin{tabular}{|c|c|c|c|c|c|c|c|c|}
\hline & \multicolumn{4}{|c|}{1979} & \multicolumn{4}{|c|}{2003} \\
\hline & \multicolumn{2}{|r|}{ Men } & \multicolumn{2}{|c|}{ Women } & \multicolumn{2}{|r|}{ Men } & \multicolumn{2}{|c|}{ Women } \\
\hline & $\begin{array}{l}\text { HS or } \\
\text { Less }\end{array}$ & $\begin{array}{c}\text { More } \\
\text { than } \underline{\mathrm{HS}}\end{array}$ & $\begin{array}{l}\text { HS or } \\
\text { Less }\end{array}$ & $\begin{array}{c}\text { More } \\
\text { than } \underline{\mathrm{HS}}\end{array}$ & $\begin{array}{l}\text { HS or } \\
\text { Less }\end{array}$ & $\begin{array}{c}\text { More } \\
\text { than } \underline{\mathrm{HS}}\end{array}$ & $\begin{array}{l}\text { HS or } \\
\text { Less }\end{array}$ & $\begin{array}{c}\text { More } \\
\text { than } \underline{\mathrm{HS}}\end{array}$ \\
\hline Years of & $0.047^{\star *}$ & $0.056^{\star *}$ & $0.036^{* *}$ & $0.09 \overline{0^{\star \star}}$ & $0.036^{\star *}$ & $0.109^{\star *}$ & $0.026^{* *}$ & $0.11 \overline{5^{\star *}}$ \\
\hline Education & $(0.005)$ & $(0.003)$ & $(0.007)$ & $(0.004)$ & $(0.004)$ & $(0.003)$ & $(0.007)$ & $(0.003)$ \\
\hline HS Degree & $0.093^{\star *}$ & & $0.105^{\star *}$ & & $0.161^{* *}$ & & $0.180^{* *}$ & \\
\hline (1=yes) & $(0.017)$ & & $(0.022)$ & & $(0.019)$ & & $(0.023)$ & \\
\hline Potential & $0.037^{\star \star}$ & $0.048^{\star *}$ & $0.027^{\star *}$ & $0.041^{\star *}$ & $0.032^{\star *}$ & $0.047^{\star *}$ & $0.029^{* *}$ & $0.043^{* *}$ \\
\hline Experience & $(0.002)$ & $(0.002)$ & $(0.002)$ & $(0.003)$ & $(0.002)$ & $(0.002)$ & (0.003) & $(0.002)$ \\
\hline Potential Exp & $-0.058^{* *}$ & $-0.092^{* *}$ & $-0.050^{* *}$ & $-0.099^{\star *}$ & $-0.049^{* *}$ & $-0.091^{* *}$ & $-0.049^{\star *}$ & $-0.088^{* *}$ \\
\hline Squared & $(0.005)$ & $(0.007)$ & $(0.005)$ & $(0.009)$ & $(0.005)$ & $(0.006)$ & $(0.006)$ & $(0.006)$ \\
\hline Race & $-0.194^{\star *}$ & $-0.098^{* *}$ & $-0.079^{* *}$ & 0.021 & $-0.136^{\star *}$ & $-0.167^{* *}$ & $-0.137^{* *}$ & $-0.060^{* *}$ \\
\hline (1=Black) & $(0.017)$ & $(0.024)$ & $(0.016)$ & $(0.022)$ & $(0.019)$ & $(0.019)$ & $(0.018)$ & $(0.015)$ \\
\hline Ethnicity & $-0.144^{* *}$ & $-0.088^{* *}$ & $-0.059^{* *}$ & -0.027 & $-0.176^{\star *}$ & $-0.221^{\star *}$ & $-0.176^{* *}$ & $-0.110^{* *}$ \\
\hline (1=Hispanic) & $(0.018)$ & $(0.024)$ & $(0.019)$ & $(0.025)$ & $(0.017)$ & $(0.021)$ & $(0.019)$ & $(0.018)$ \\
\hline Part time wkr & $-0.159^{* *}$ & $-0.217^{\star *}$ & $-0.201^{\star *}$ & $-0.175^{\star \star}$ & $-0.300^{\star *}$ & $-0.329^{\star *}$ & $-0.210^{* *}$ & $-0.165^{\star *}$ \\
\hline (1=part time) & $(0.044)$ & $(0.040)$ & $(0.016)$ & $(0.025)$ & $(0.041)$ & $(0.039)$ & $(0.019)$ & $(0.016)$ \\
\hline Marital Status & $0.229^{\star *}$ & $0.177^{* *}$ & $0.029^{*}$ & 0.033 & $0.172^{\star \star}$ & $0.198^{\star *}$ & $0.095^{\star *}$ & $0.131^{\star *}$ \\
\hline$(1=$ married $)$ & $(0.014)$ & $(0.016)$ & $(0.014)$ & $(0.017)$ & $(0.014)$ & $(0.013)$ & $(0.019)$ & $(0.016)$ \\
\hline Hhold Status & & & $0.041^{*}$ & $0.073^{\star *}$ & & & $0.072^{\star *}$ & $0.052^{\star \star}$ \\
\hline (1=Single Mom) & & & $(0.018)$ & $(0.026)$ & & & $(0.021)$ & $(0.018)$ \\
\hline Number of & 0.004 & $0.013^{* *}$ & $-0.018^{* *}$ & $-0.039^{* *}$ & $0.009^{*}$ & 0.006 & $-0.011^{*}$ & $-0.015^{\star *}$ \\
\hline Children & $(0.003)$ & $(0.004)$ & $(0.004)$ & $(0.007)$ & $(0.004)$ & $(0.003)$ & $(0.005)$ & $(0.004)$ \\
\hline Number of & -0.005 & -0.017 & 0.008 & $0.032^{*}$ & 0.003 & $0.030^{* *}$ & 0.001 & $0.029^{\star \star}$ \\
\hline Preschoolers & $(0.008)$ & $(0.009)$ & $(0.009)$ & $(0.014)$ & $(0.009)$ & $(0.008)$ & $(0.011)$ & $(0.009)$ \\
\hline Number of & 0.005 & $0.029^{*}$ & $0.024^{*}$ & $0.040^{*}$ & -0.011 & -0.020 & 0.025 & 0.011 \\
\hline Infants & $(0.012)$ & (0.013) & $(0.012)$ & $(0.019)$ & $(0.014)$ & $(0.012)$ & (0.017) & (0.013) \\
\hline Observation & 19441 & 13674 & 14028 & 8767 & 17014 & 22616 & 12848 & 21726 \\
\hline
\end{tabular}

Note: All regressions include controls for location (SMSA) and state fixed effects. Potential experience is defined as age-education-5; coefficient on potential experience squared is multiplied by 100 . Number of children is the total number of children in the family less than age 18; number of preschoolers is the total less than age 6; and number of infants is the total less than age 2. Wages are inflation-adjusted to 2000 dollars using the GDP Personal Consumption Expenditure deflator.

* Significant at $5 \%$ level or higher. Standard errors in parentheses.

** Significant at $1 \%$ level of higher. 
Table 4

Comparative Sources of Change in Labor Force Participation

\begin{tabular}{|c|c|c|c|c|c|c|}
\hline & \multicolumn{3}{|c|}{ Low-skilled Women vs. Low-Skilled Men } & \multicolumn{3}{|c|}{ Low-skilled Women vs. More-skilled Women } \\
\hline & \multicolumn{2}{|c|}{$\begin{array}{c}\text { Change in Labor Force } \\
\text { Participation }\end{array}$} & \multirow[b]{2}{*}{ Difference } & \multicolumn{2}{|c|}{$\begin{array}{c}\text { Change in Labor Force } \\
\text { Participation }\end{array}$} & \multirow[b]{2}{*}{ Difference } \\
\hline & Women & Men & & Less-skilled & More-skilled & \\
\hline 2003 Level & 54.7 & 71.4 & -16.7 & 54.7 & 65.8 & -11.1 \\
\hline 1979 Level & 46.4 & 77.9 & -31.5 & 46.4 & 55.8 & -9.4 \\
\hline Total Change & 8.3 & -6.5 & 14.8 & 8.3 & 10.0 & -1.7 \\
\hline \multicolumn{7}{|l|}{ Change due to: } \\
\hline Education & -2.0 & -10.2 & 8.2 & -2.0 & -15.4 & 13.4 \\
\hline Potl Experience & 8.2 & 5.2 & 3.0 & 8.2 & 3.0 & 5.2 \\
\hline Family Comp & 13.9 & -1.0 & 14.9 & 13.9 & 9.3 & 4.6 \\
\hline Other Variables & -11.8 & -0.5 & -11.3 & -11.8 & 13.1 & -24.9 \\
\hline \multicolumn{7}{|c|}{ Change due to means changes only: } \\
\hline Education & 0.8 & 0.7 & 0.1 & 0.8 & -0.4 & 1.2 \\
\hline Potl Experience & 1.0 & 1.0 & 0.0 & 1.0 & 2.5 & -1.5 \\
\hline Family Comp & 1.7 & -3.1 & 4.8 & 1.7 & 1.5 & 0.2 \\
\hline Other Variables & 0.0 & 1.4 & -1.4 & 0.0 & 0.3 & -0.3 \\
\hline \multicolumn{7}{|c|}{ Change due to coefficients changes only: } \\
\hline Education & -2.8 & -11.0 & 8.2 & -2.8 & -15.0 & 12.2 \\
\hline Potl Experience & 7.1 & 4.3 & 2.8 & 7.1 & 0.5 & 6.6 \\
\hline Family Comp & 12.2 & 2.1 & 10.1 & 12.2 & 7.8 & 4.4 \\
\hline Other Variables & -11.7 & -1.9 & -9.8 & -11.7 & 12.8 & -24.5 \\
\hline
\end{tabular}

Based on estimated regressions shown in Table 2. 
Table 5

Comparative Sources of Change in Log Wages

\begin{tabular}{|c|c|c|c|c|c|c|}
\hline & \multicolumn{3}{|c|}{ Low-skilled Women vs. Low-Skilled Men } & \multicolumn{3}{|c|}{ Low-skilled Women vs. More-skilled Women } \\
\hline & \multicolumn{3}{|c|}{ Change in Real Log Wages } & \multicolumn{3}{|c|}{ Changes in Real Log Wages } \\
\hline & Women & Men & Difference & Less-skilled & More-skilled & Difference \\
\hline 2003 Level & 2.300 & $\overline{2.517}$ & -0.217 & 2.300 & 2.726 & -0.426 \\
\hline 1979 Level & 2.166 & 2.582 & -0.416 & 2.166 & 2.430 & -0.264 \\
\hline Total Change & 0.134 & -0.065 & 0.199 & 0.134 & 0.296 & -0.162 \\
\hline \multicolumn{7}{|l|}{ Change due to: } \\
\hline Education & -0.042 & -0.065 & 0.023 & -0.042 & 0.348 & -0.390 \\
\hline Potl Experience & 0.086 & -0.017 & 0.103 & 0.086 & 0.132 & -0.046 \\
\hline Family Comp & 0.055 & -0.060 & 0.115 & 0.055 & 0.089 & -0.034 \\
\hline Other Variables & 0.036 & 0.077 & -0.041 & 0.036 & -0.273 & 0.309 \\
\hline \multicolumn{7}{|c|}{ Change due to means changes only: } \\
\hline Education & 0.009 & 0.015 & -0.006 & 0.009 & -0.021 & 0.030 \\
\hline Potl Experience & 0.039 & 0.030 & 0.009 & 0.039 & 0.083 & -0.044 \\
\hline Family Comp & 0.001 & -0.031 & 0.032 & 0.001 & 0.008 & -0.007 \\
\hline Other Variables & -0.028 & -0.034 & 0.006 & -0.028 & -0.016 & -0.012 \\
\hline \multicolumn{7}{|c|}{ Change due to coefficients changes only: } \\
\hline Education & -0.051 & -0.081 & 0.030 & -0.051 & 0.369 & -0.420 \\
\hline Potl Experience & 0.046 & -0.047 & 0.093 & 0.046 & 0.049 & -0.003 \\
\hline Family Comp & 0.054 & -0.029 & 0.083 & 0.054 & 0.081 & -0.027 \\
\hline Other Variables & 0.064 & 0.111 & -0.047 & 0.064 & -0.257 & 0.321 \\
\hline
\end{tabular}

Based on estimated regressions shown in Table 3. 
Figure 1

Labor Force Participation by Skill Level, by Gender

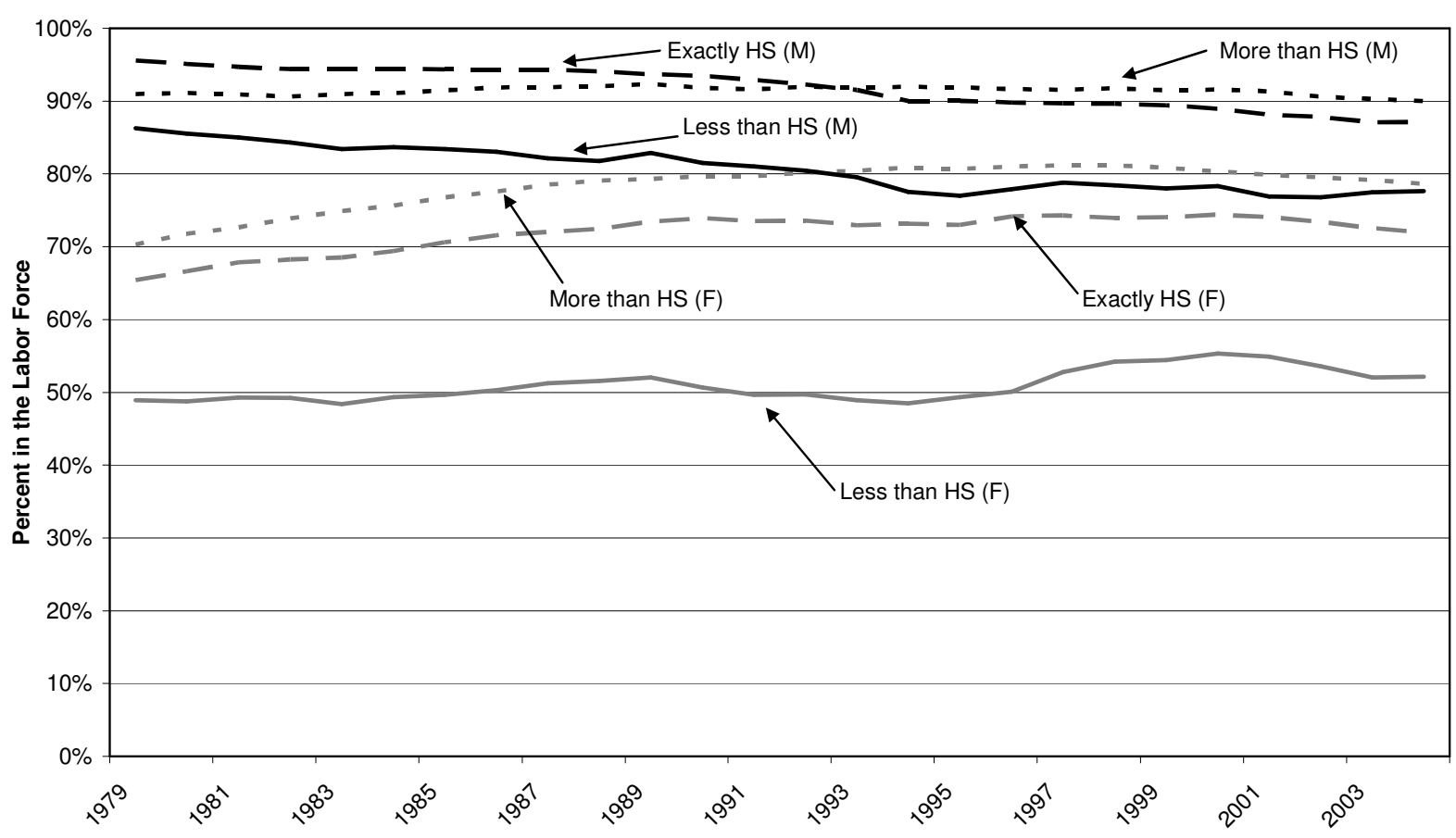

Source: Authors' tabulations from Current Population Survey Outgoing Rotation Group data, 1979 to 2004.

Year Based on all noninstitutionalized civilian adults aged 18-54.

Figure 2

\section{Unemployment Rates by Skill Level, by Gender}

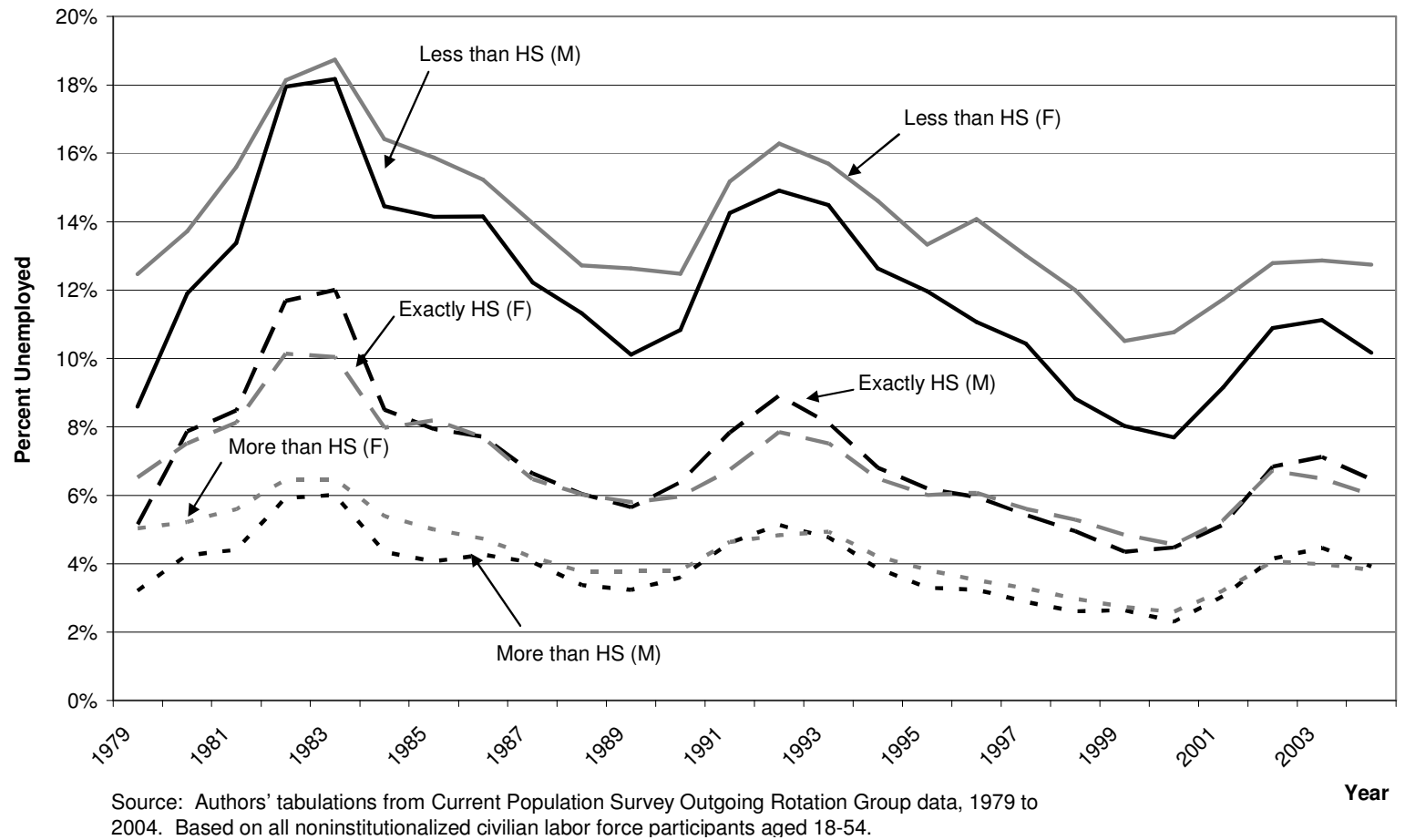


Figure 3

Real Median Hourly Wage Rates by Skill Level, by Gender

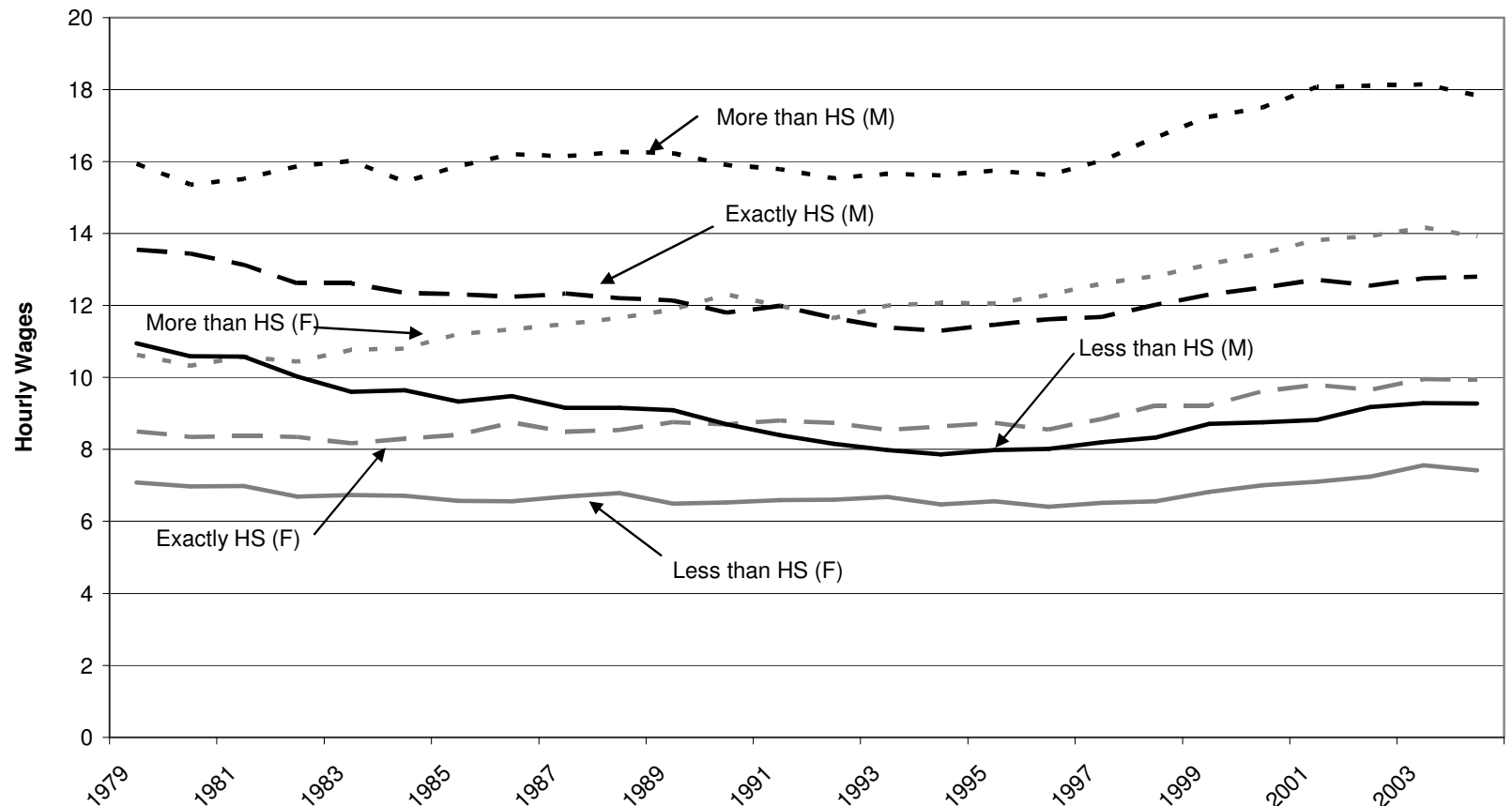

Source: Authors' tabulations from Current Population Survey Outgoing Rotation Group data, 1979 to 2004. Based Year on all noninstitutionalized civilian workers aged 18-54. Inflation adjusted to 2000 dollars.

Figure 4

Years of Full-Time Work Experience by Age, by Gender 1979 and 2000, Less-Skilled Workers Only

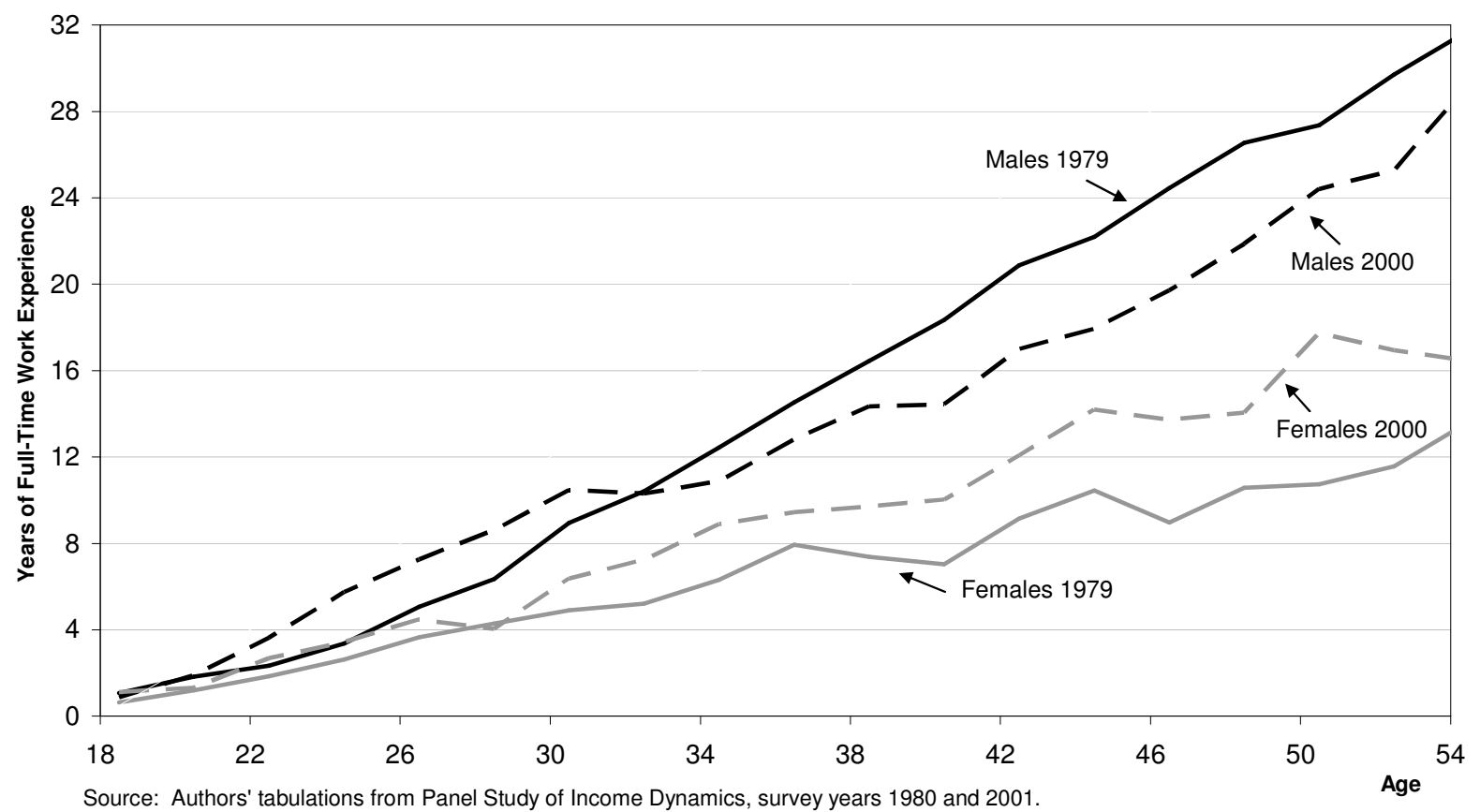

Based on all noninstitutionalized civilian adults aged 18-54 with a high school degree or less. 
Figure 5

Labor Force Participation by Years of Full-Time Work Experience, by Gender 1979 and 2000, Less-Skilled Workers Only

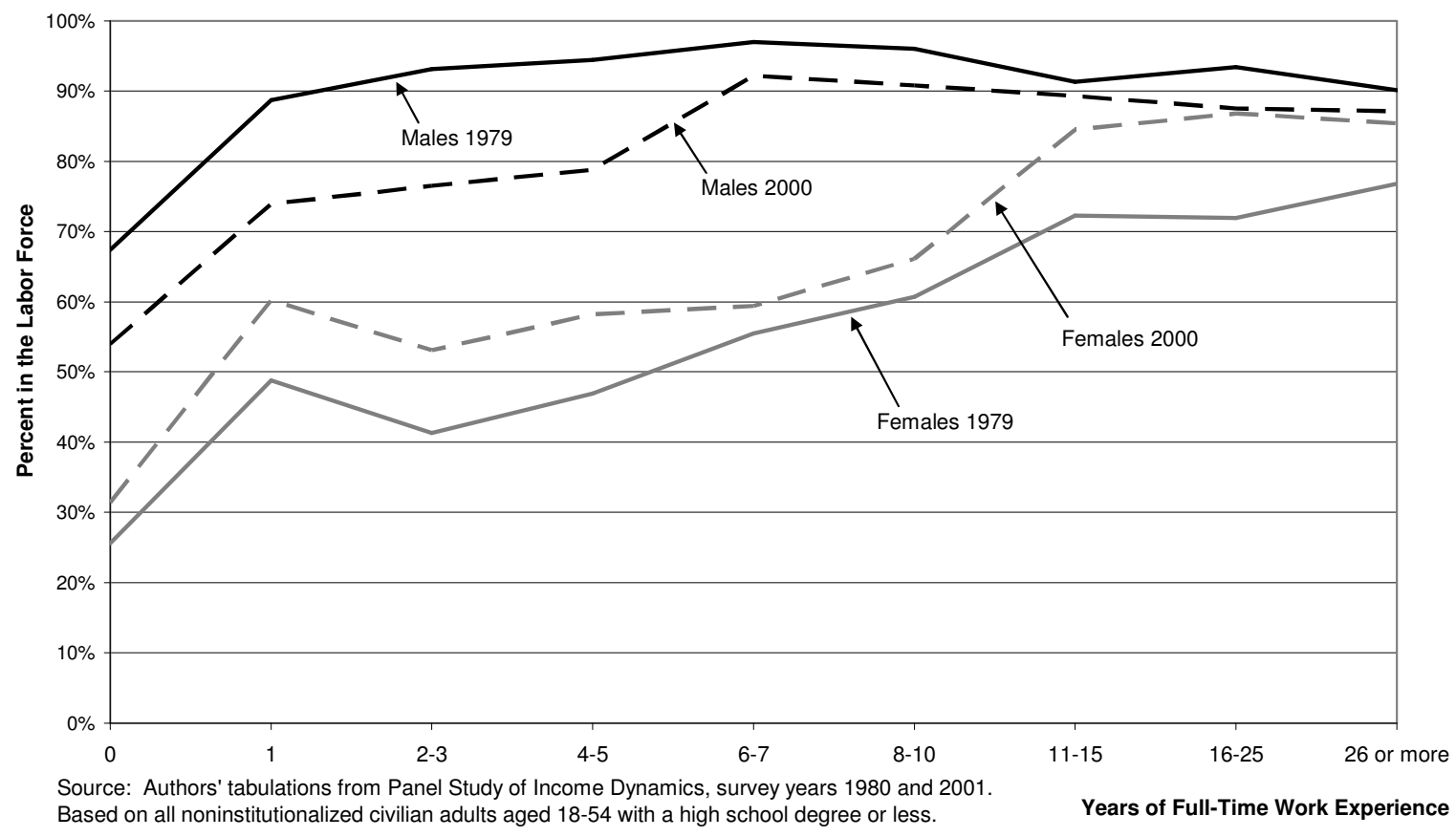

Figure 6

Median Hourly Wages By Years of Full-Time Work Experience, by Gender 1979 and 2000, Less-Skilled Workers only

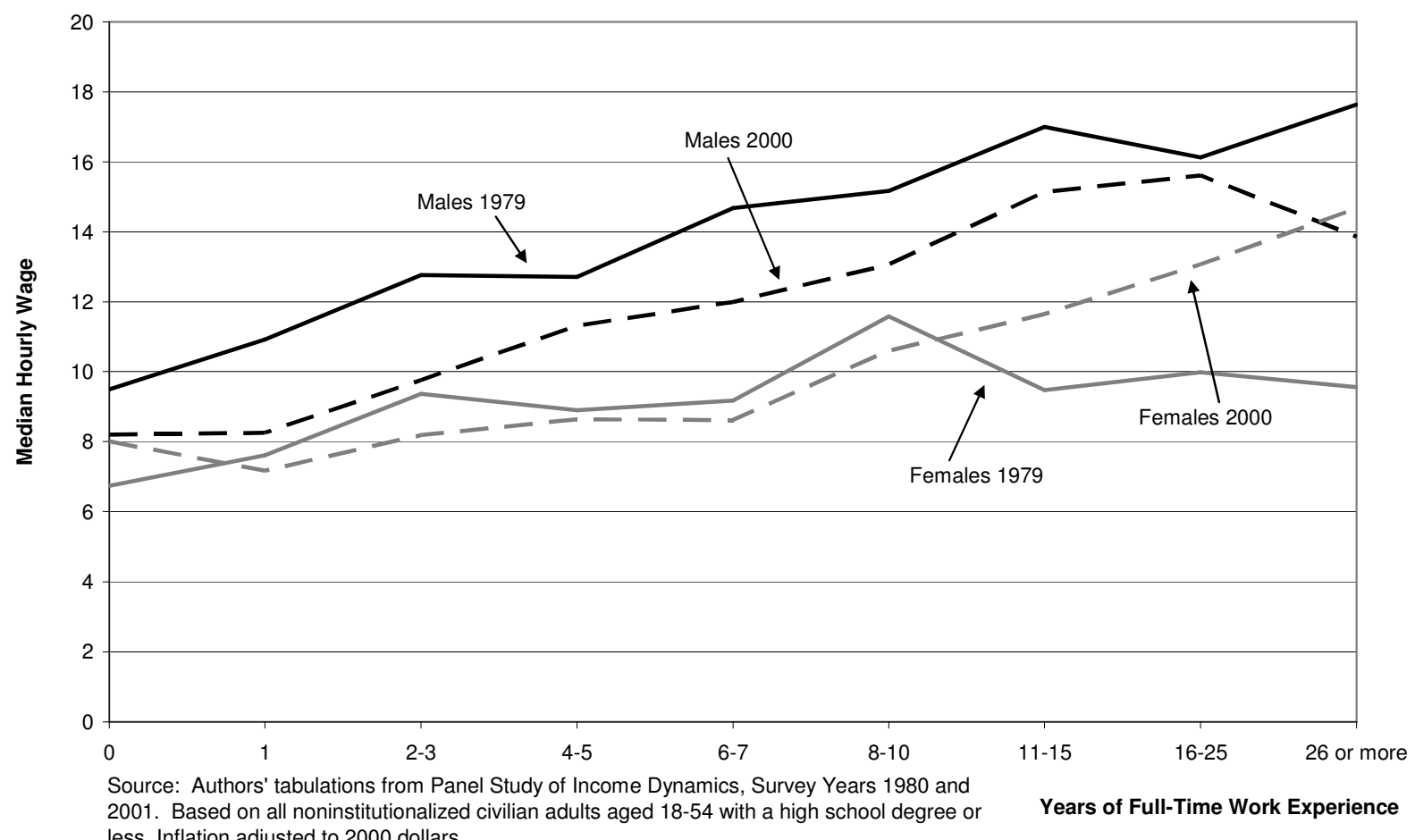


Figure 7

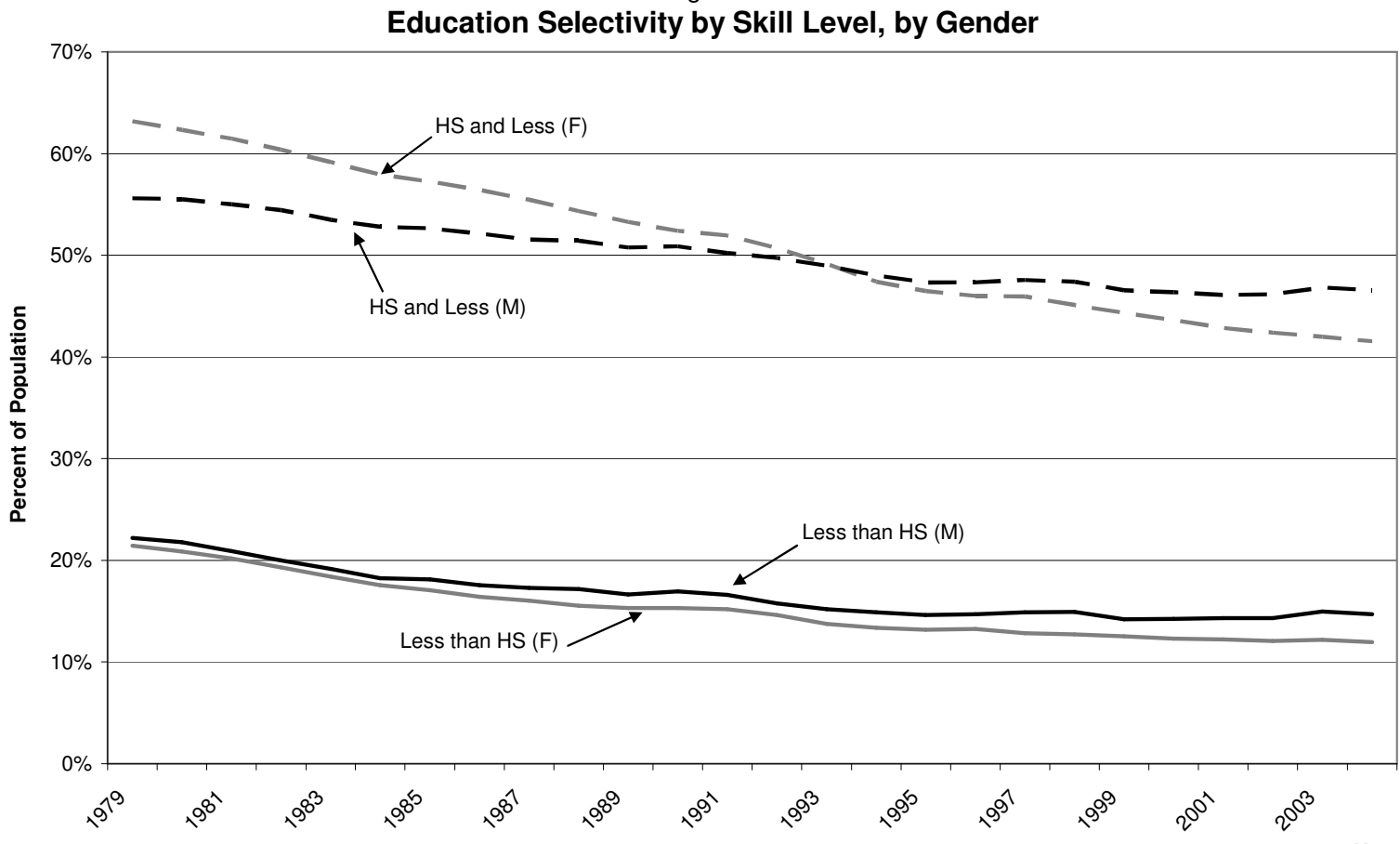

Source: Authors' tabulations from Current Population Survey Outgoing Rotation Group data, 1979 to 2004. Based on all noninstitutionalized civilian adults aged $18-54$

Figure 8

Labor Force Participation by Years of Education, by Gender 1979 and 2000

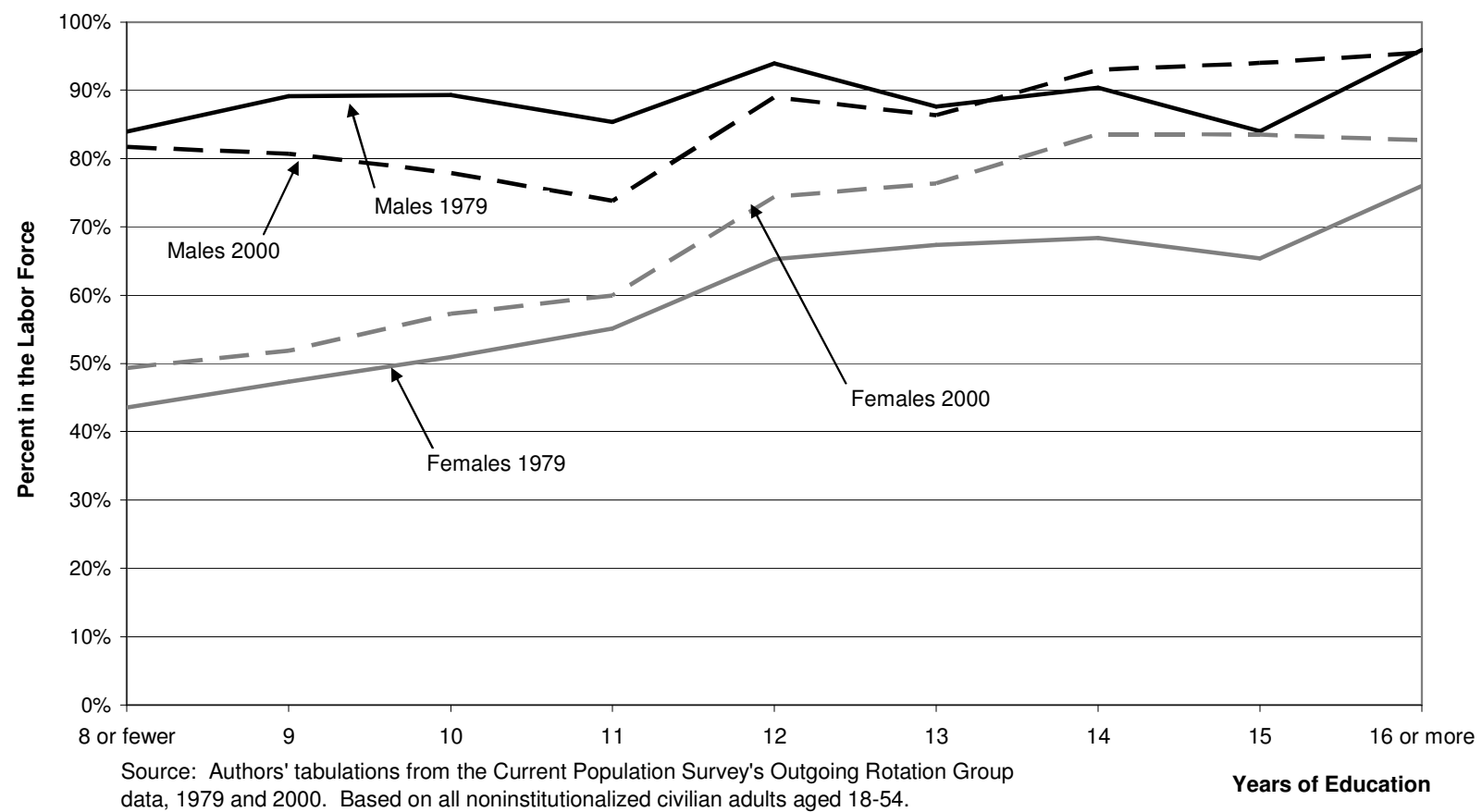


Figure 9

Median Hourly Wages by Years of Education, by Gender

1979 and 2000

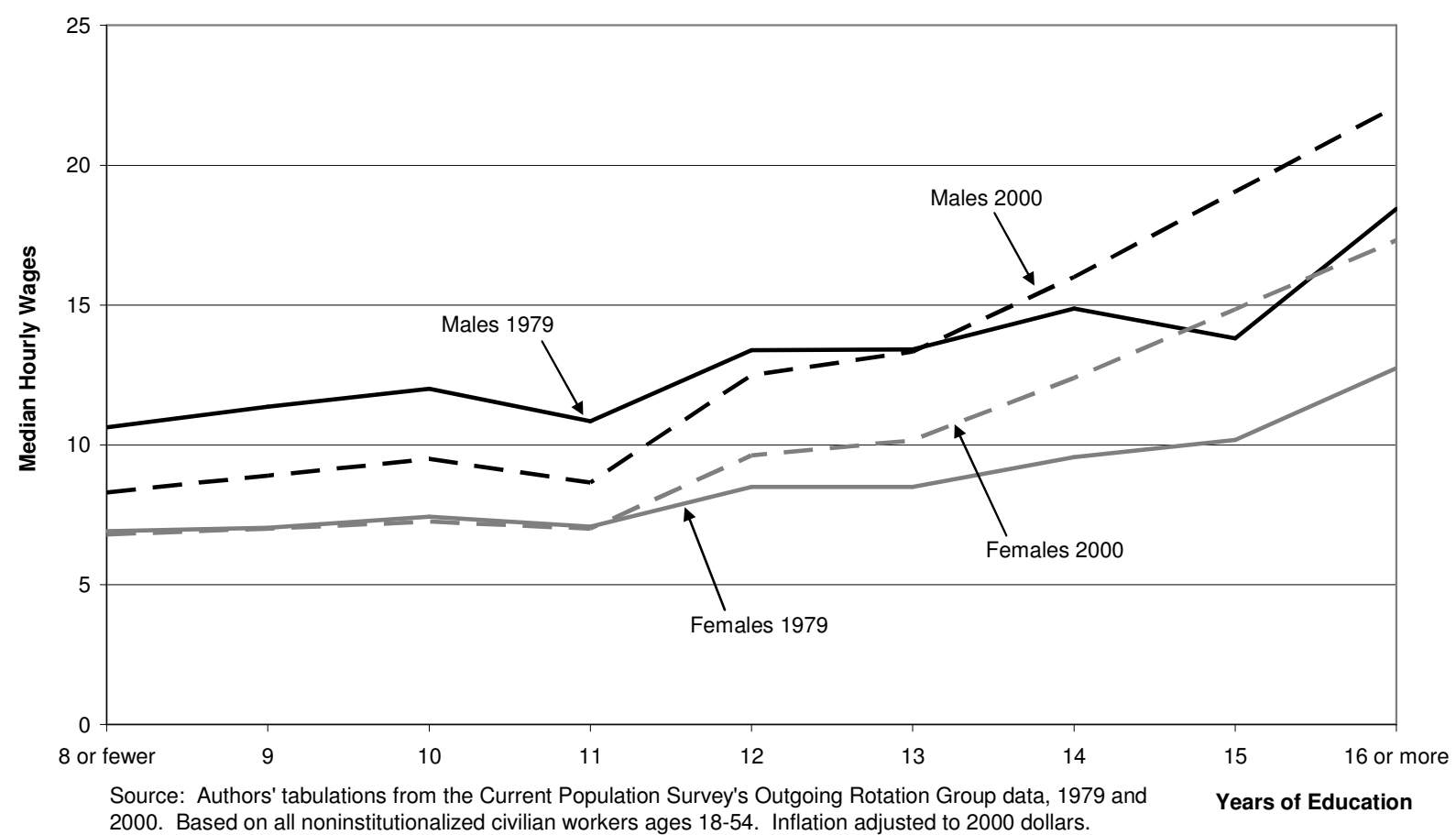

Figure 10

Industry Location Among Less-Skilled Workers, by Gender, 2002

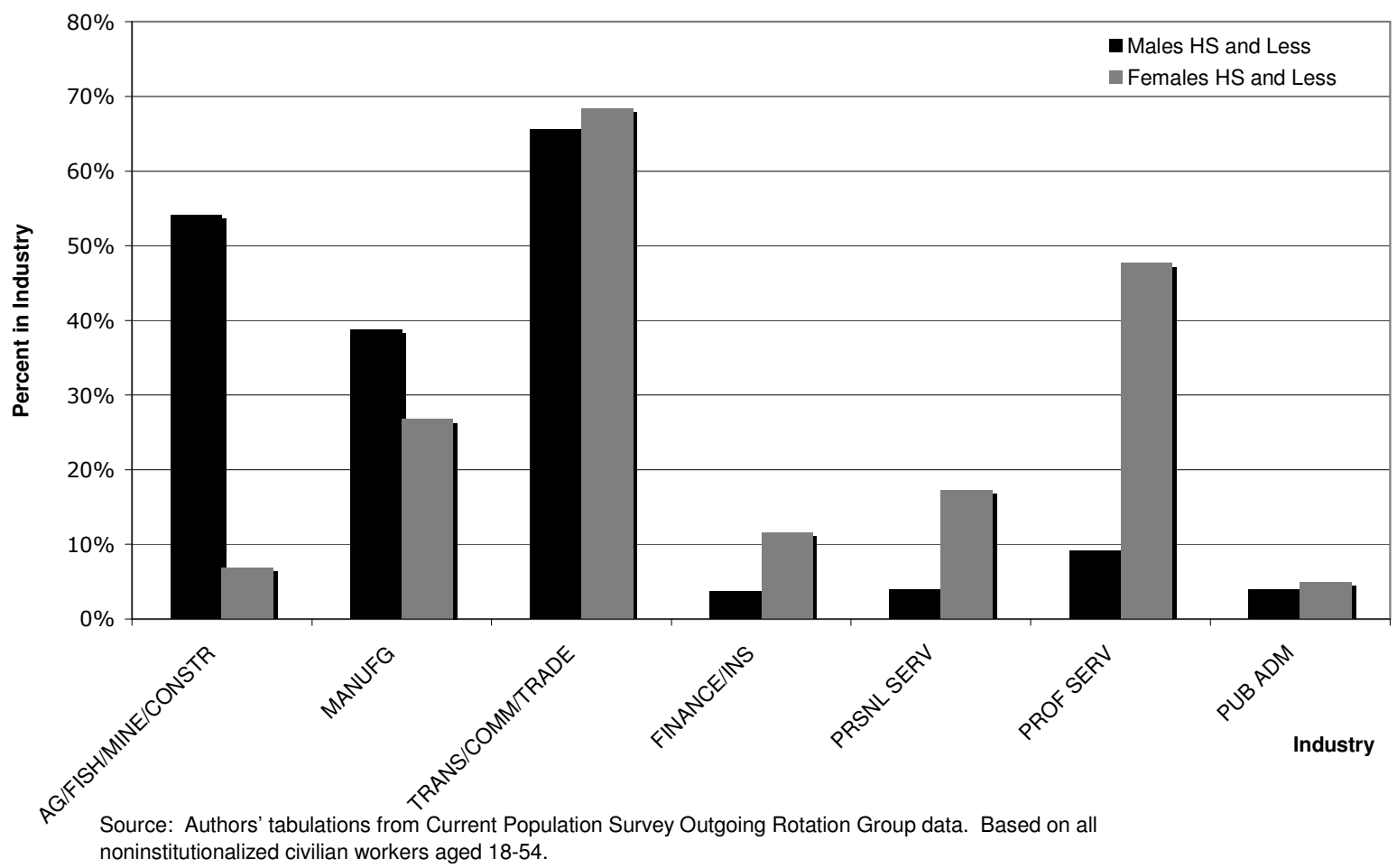

